\begin{tabular}{|c|l|}
\hline Title & Role of the equatorial Kelvin wave in stratosphere troposphere exchange in a general circulation model \\
\hline Author(s) & Fujiwara, Masatomo; Takahashi, Masaaki \\
\hline Citation & $\begin{array}{l}\text { Journal of Geophysical Research: A tmospheres, 106(D19), 22763_22780 } \\
\text { https:/doi.org/_0.1029/2000JD000161 }\end{array}$ \\
\hline Issue Date & 2001-10_16 \\
\hline Doc URL & http://hdl.handle.net/2115/64860 \\
\hline Rights & Copyright 2001_A merican Geophysical Union. \\
\hline Type & article \\
\hline File Information & Fujiwara_et_al-2001-Journal_of_Geophysical_Research_Atmospheres_(1984_2012).pdf \\
\hline
\end{tabular}

Instructions for use 


\title{
Role of the equatorial Kelvin wave in stratosphere-troposphere exchange in a general circulation model
}

\author{
Masatomo Fujiwara ${ }^{1}$ \\ Division of Ocean and Atmospheric Sciences, Graduate School of Environmental Earth Science, \\ Hokkaido University, Sapporo, Japan \\ Masaaki Takahashi \\ Center for Climate System Research, University of Tokyo, Tokyo, Japan
}

\begin{abstract}
Large-scale disturbances which cause the variations of ozone and water around the equatorial tropopause are investigated with a general circulation model incorporating a simplified ozone photochemistry, realistic topography, and seasonal cycle of the sea surface temperature. Eastward moving large-scale equatorial gravity waves are found to be dominant to modulate the minor constituents' distribution around the equatorial tropopause. A case over the Indian Ocean in the northern summer was investigated in detail. The disturbance had the characteristics of the equatorial Kelvin wave at the tropopause level, coupled with organized active convections in the troposphere. Associated with the downward displacement (and suppressed-convection) phase of this system, dry, ozone-rich stratospheric air moved downward into the upper troposphere. At the opposite phase, physical and dynamical processes above the organized active convections prevented the lower stratosphere from accumulating excess water. Thus the dryness around the equatorial tropopause is maintained during the passage of such a system. Analysis of 4-year integration data reveals that such disturbances are especially active over the Indian Ocean during the northern summer through autumn. This is probably related to the development of the summer monsoon circulation over south Asia. This model has also simulated the zonal wave one structure of tropical tropospheric ozone and suggested the important contribution of convective transport to the structure.
\end{abstract}

\section{Introduction}

Transport of mass and chemical species across the tropopause, often called stratosphere-troposphere exchange (STE), is one of the important processes controlling the photochemical and radiative balance of the Earth's atmosphere [e.g., Holton et al, 1995]. The history of research on STE began with Brewer [1949], who postulated a global meridional circulation in the stratosphere, now often called Brewer-Dobson circulation (after the works by Dobson et al. [1929] and Dobson [1956] as well), from some stratospheric water vapor data over England. Later, Mote et al. [1996] visualized the trop-

\footnotetext{
${ }^{1}$ Now at Radio Science Center for Space and Atmosphere (RASC), Kyoto University, Uji, Japan
}

Copyright 2001 by the American Geophysical Union.

Paper number 2000JD000161.

0148-0227/01/2000JD000161\$09.00 ical upward branch of this circulation with a satellite data analysis. Brewer's point was that the tropospheric air should enter the stratosphere only through the tropical tropopause, the coldest tropopause in the world, where the air is dried by condensation; afterward, the air should travel in the stratosphere to higher latitudes to maintain the dryness of the global stratosphere. The drying process at the tropical tropopause is called "cold trap" or "dehydration." Since Brewer's paper, tropical STE has always been discussed in terms of water vapor transport or dehydration mechanism. (See section 7 of Kley et al. [1979] for the discussions in the 1970s.) On the basis of the idea that the lower stratospheric water vapor concentration should satisfy the saturation condition at the tropopause somewhere in the tropics, Newell and Gould-Stewart [1981] tried to specify the upward transport region by utilizing the monthly mean temperature data at $100 \mathrm{hPa}$ in the tropics and the water vapor sounding data over Brazil. The analysis showed that such a region would be limited seasonally and lon- 
gitudinally to the "stratospheric fountain" regions, that is, the Indonesian maritime continent in the northern winter and the Bay of Bengal and India in the northern summer because the $100-\mathrm{hPa}$ temperatures are not sufficiently cold even for much of the tropics. Although recently there are some disputes on this "fountain" hypothesis [e.g., Holton et al., 1995; Dessler, 1998; Vömel and Oltmans, 1999; Sherwood, 2000], it still is the basic one.

Tropical STE would occur associated with a slow mean rising motion through the tropopause and/or some meteorological disturbances affecting the tropopause region. A dominant contribution of the former process which Brewer [1949] had originally postulated was questioned by Holton [1984], who discussed that such a motion should require the formation of a thick uniform cloud layer near the tropopause but that such clouds are not observed. Recent satellite observations, however, have revealed that optically thin (subvisible or subvisual) cirrus clouds are frequently present near the tropopause [e.g., Wang et al., 1996; Winker and Trepte, 1998]. Also, a theoretical work in the early 1990s has given the dynamical basis for the Brewer-Dobson circulation as driven by extratropical eddy-induced drag force [Haynes et al., 1991; see also Holton et al., 1995]. These findings may imply that a slow upward advection makes a certain contribution to the tropical STE. However, what has drawn much attention since the early $1980 \mathrm{~s}$ is the cumulonimbus cloud, which may directly affect the tropopause region and may even penetrate/overshoot into the lower stratosphere. There is a reason to focus on deep convection because the fountain regions, which have a colder tropopause, coincide with the area of strong convection. One of the requirements that any dehydration mechanism should satisfy is that the ice particles formed near the tropopause should become large enough to fall out and not be carried up again to reevaporate in the lower stratosphere. Danielsen [1982] proposed such a mechanism in radiatively destabilized anvils in overshooting cumulonimbus clouds from the results of the first intensive aircraft observation of tropical STE conducted at Panama in August-September 1980 (see the special issue in Geophysical Research Letters, $9(6)$, 599-624, 1982). As a test of the Danielsen's model in a fountain region, another aircraft mission was conducted at Darwin, Australia, in January-February 1987 (see the special issue in Journal of Geophysical Research, 98(D5), 8561-8773, 1993). These two campaigns confirmed that cumulonimbus clouds can penetrate into the lower stratosphere to mix the tropospheric and stratospheric air around the tropopause, and the Darwin results showed that some dehydration processes did occur at the top of the penetrating clouds [see Holton et al., 1995]. Vömel et al. [1995] also observed a strong connection between the water vapor content near the equatorial tropopause and deep convections. However, it is still unclear how frequent and effective such cumulonimbus cloud processes are for the tropical stratospheric mass and water vapor budget. Another type of disturbance which may contribute to the dehydration is small-scale fluctuations in temperature in the lower stratosphere, that is, the atmospheric gravity/buoyancy waves mainly generated by the convections below [e.g., Potter and Holton, 1995]. Potter and Holton discussed that the cloud particles produced and enlarged at the cold phase of such waves would eventually fall out to make a contribution to the dryness of the tropical lower stratosphere.

As seen in the above, aside from the Brewer-Dobson circulation, most of the researchers have been focusing on small-scale disturbances as the agent of tropical STE rather than large-scale or synoptic-scale disturbances. However, there is an early work by Parker [1973], who found marked disturbances with a period of about a month, confined around the tropical tropopause, between $150 \mathrm{hPa}$ and $70 \mathrm{hPa}$, from the analysis of global tropical station data. He carefully investigated their various features and concluded that most of them should be regarded as the equatorial Kelvin wave, one of the eastward moving planetary-scale equatorial gravity waves [e.g., Matsuno, 1966; Wallace and Kousky, 1968; Andrews et al., 1987]. Madden and Julian [1972] also pointed out the existence of an eastward propagating disturbance at the tropopause, being associated with a 40 to 50-day oscillation in the tropical troposphere which is now often called the Madden-Julian oscillation (MJO) or the intraseasonal oscillation (ISO) (see their section 12). The role of the equatorial Kelvin wave on the tropical STE was first suggested by Tsuda et al. [1994], who made radiosonde soundings in Indonesia in February-March 1990 and observed a tropopause temperature variation between $185 \mathrm{~K}$ and $193 \mathrm{~K}$ with a period of about 20 days (see their section 4.2). Holton et al. [1995] noted the advantage of such a longerperiod wave for the effective dehydration because the ice particles can become large enough to fall out during such a long duration of its cold phase. It was Fujiwara et al. [1998] who first observed a tropical ozone STE event associated with an equatorial Kelvin wave around the tropopause and the coupled organized convections in the troposphere, by conducting an intensive observation with ozonesondes and radiosondes in Indonesia in May-June 1995. They summarized the observed ozone-transporting eastward moving system in their Figure 9: Downward displacement associated with the Kelvin wave around the tropopause and subsidence during the nonconvective phase of $\mathrm{MJO}$ together caused ozone transport from the stratosphere into the troposphere, and the air mixing due to the breaking phase of this Kelvin wave also resulted in ozone transport. Recently, Boehm and Verlinde [2000] analyzed the radiosonde and micropulse lidar data taken at Nauru in the western Pacific and showed that cirrus clouds ap- 
peared selectively at the cold phases of the Kelvin wave near the tropopause. Also, as a part of the project Soundings of Ozone and Water in the Equatorial Region (SOWER)/Pacific mission, some water vapor soundings were made by using the balloon-borne cryogenic frost point hygrometer at San Cristóbal Island, Ecuador, in September 1998 and revealed the role of the Kelvin wave in controlling the water vapor concentration around the tropopause [Fujiwara et al., 2001].

In the present study, we aim to investigate the role of large-scale disturbances such as Kelvin waves in the tropical STE by using an atmospheric general circulation model (GCM) which incorporates a simple ozone photochemistry. Previous studies using this model have succeeded in internally simulating a quasi-biennial oscillation (QBO) in zonal wind in the equatorial lower stratosphere [Takahashi, 1996; Takahashi et al., 1997; Takahashi, 1999] and ozone QBO [Nagashima et al., 1998] for the first time as a GCM. They confirmed that one of the keys for success was to set the vertical resolution as $500 \mathrm{~m}$, finer than that of other GCMs, to allow simulating finer-vertical-scale gravity waves. We consider that this is also essential to simulate a realistic activity of large-scale disturbances at the tropical tropopause [cf., Lindzen and Fox-Rabinovitz, 1989]. In sections 2 and 3 , we will explain the present model in detail and show some of the basic performance of the model. We will investigate a case resembling the one observed by Fujiwara et al. [1998] in section 4 and describe the seasonal and longitudinal dependences of the activity of large-scale disturbances at the equatorial tropopause in section 5 . Section 6 summarizes the findings.

\section{Model Description}

The model is the first version of the atmospheric general circulation model developed at the Center for Climate System Research/National Institute for Environmental Studies (CCSR/NIES). The spectral transform method is used in the horizontal, and finite differences are used in the vertical for the dynamical equations. Other basic components of the model are explained by Numaguti [1993]. Newly implemented physical processes are discussed by Numaguti et al. [1995]. A detailed description of the radiation scheme is presented by Nakajima et al. [1995].

The model for the present study is basically the same as used by Nagashima et al. [1998], but the horizontal resolution is $\mathrm{T} 42$, corresponding to about $2.8^{\circ} \times 2.8^{\circ}$ grids. There are 60 sigma $(\sigma)$ levels in vertical, where $\sigma \equiv P / P_{s}, P$ is pressure, and $P_{s}$ is surface pressure, with the top boundary at about $50-\mathrm{km}$ altitude, resulting in 550-m vertical spacing at 8 to $25-\mathrm{km}$ altitudes. Note that the vertical spacing has been slightly changed from that of Nagashima et al. Rayleigh friction with 10day damping is used near the top boundary. The 4-day damping time for the maximum wave number is ap- plied in the fourth-order horizontal nonlinear diffusion. The prognostic Arakawa-Schubert scheme is used for the cumulus parameterization (see the description by Numaguti [1999] for further details of the hydrological processes in this model). Stratospheric ozone is simulated with a modified Chapman mechanism, a simple ozone photochemistry incorporating only oxygen atoms, $\mathrm{O}_{2}$, and $\mathrm{O}_{3}$, with some of the reaction constants modified to produce realistic values of ozone concentration in the stratosphere (see the description by Nagashima et al. for the details). The ozone distribution in the troposphere is primarily determined by the flux from the stratosphere, transport within the troposphere, and dry deposition at the surface in this model. The vertical diffusion coefficient for the minor constituents including water vapor is the same as the thermal diffusion coefficient which is determined locally from the Richardson number (the Mellor-Yamada level 2 closure scheme [Mellor and Yamada, 1974]). The magnitude of the minimum vertical diffusion coefficient is set to $0.1 \mathrm{~m}^{2}$ $\mathrm{s}^{-1}$. The dry convective adjustment scheme is applied to simulate the gravity wave breaking in the stratosphere. The momentum deposition by subgrid-scale orographically excited gravity waves is parameterized with the McFarlane scheme [McFarlane, 1987]. Every month has equally 30 days, and a year consists of 360 days in this experiment. For example, August 1 corresponds to day 211, and September 1 corresponds to day 241. A realistic topography and annual cycle of the sea surface temperature (SST) by month are considered as the boundary conditions.

The initial field for this experiment was prepared from Nagashima et al.'s result on August 16 of the eleventh year. We suitably interpolated their T21 data set to make a T42 data set and started the integration. On November 1 of the eleventh year the vertical spacing has been changed slightly from Nagashima et al.'s to the one described above. Then, we made an $~ 4-$ year integration until the last day of the fifteenth year. The outputs are the daily-averaged meteorological parameters, ozone volume mixing ratio, etc. Before the analyses, all the parameters on the $60 \sigma$ levels are projected onto the 60 pressure levels (in this paper, $P_{i}$ was set as $\sigma_{i} \times 1000$, where $i=1 \sim 60$ ), and the altitude is calculated from the relation, $Z_{i}=-H \ln \left(P_{i} / 1000\right)$, where $H=7 \mathrm{~km}$ (see the inner ticks of the following figures). We use the 4-year data between the first day of the twelfth year and the last day of the fifteenth year in the following analyses.

\section{Climatological Features of the Model}

Figure 1 shows the zonal mean distributions of temperature, zonal wind, and ozone mixing ratio for January and July of the fifteenth year. The model has simulated the basic characteristics of the atmosphere qualitatively in all the months. Compared to the observations and the model results from the National Center 


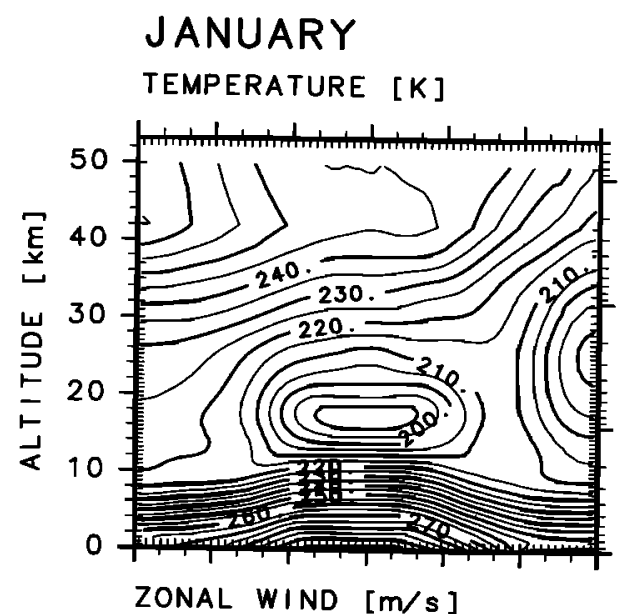

\author{
JULY \\ TEMPERATURE [K]
}
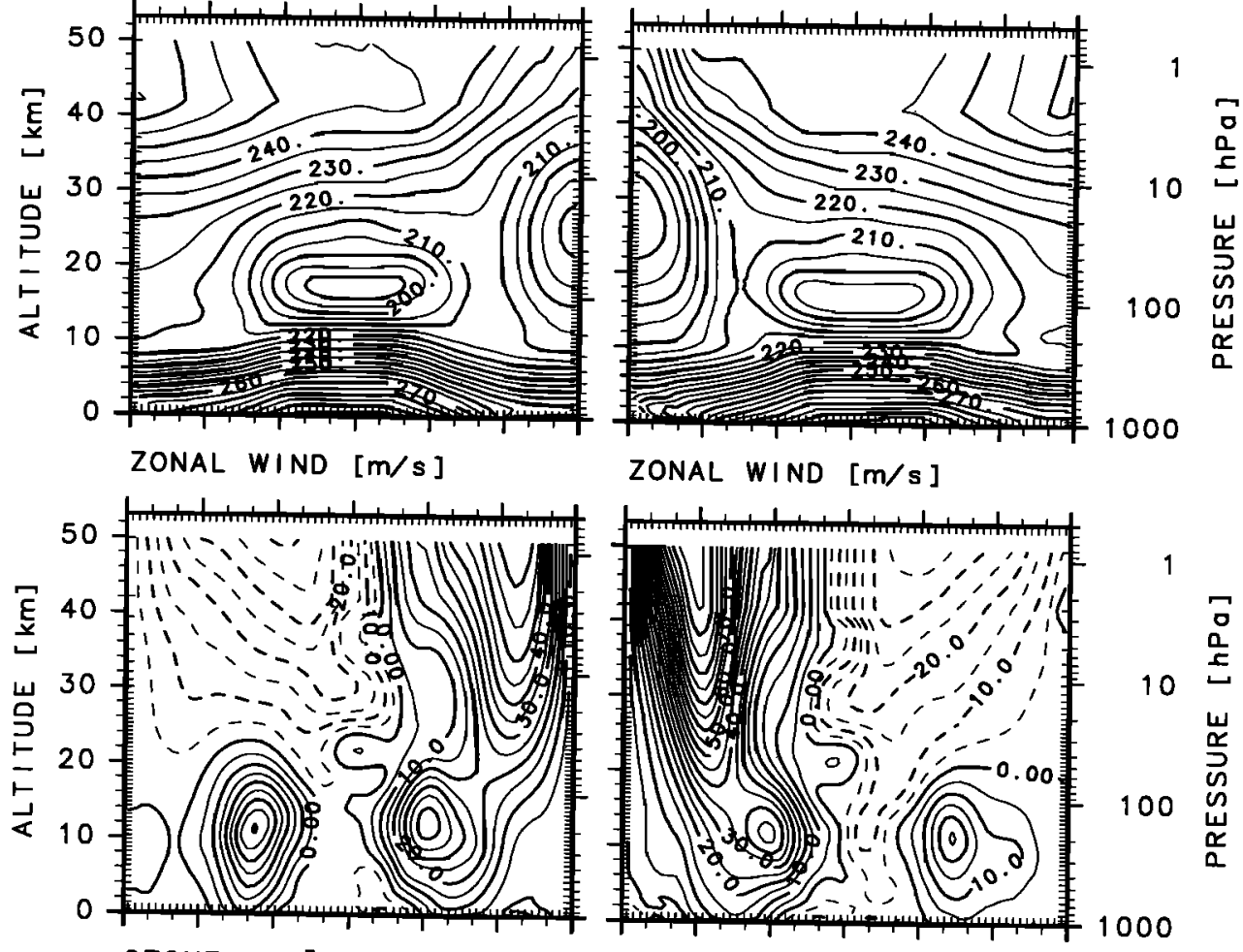

ZONAL WIND $[\mathrm{m} / \mathrm{s}]$
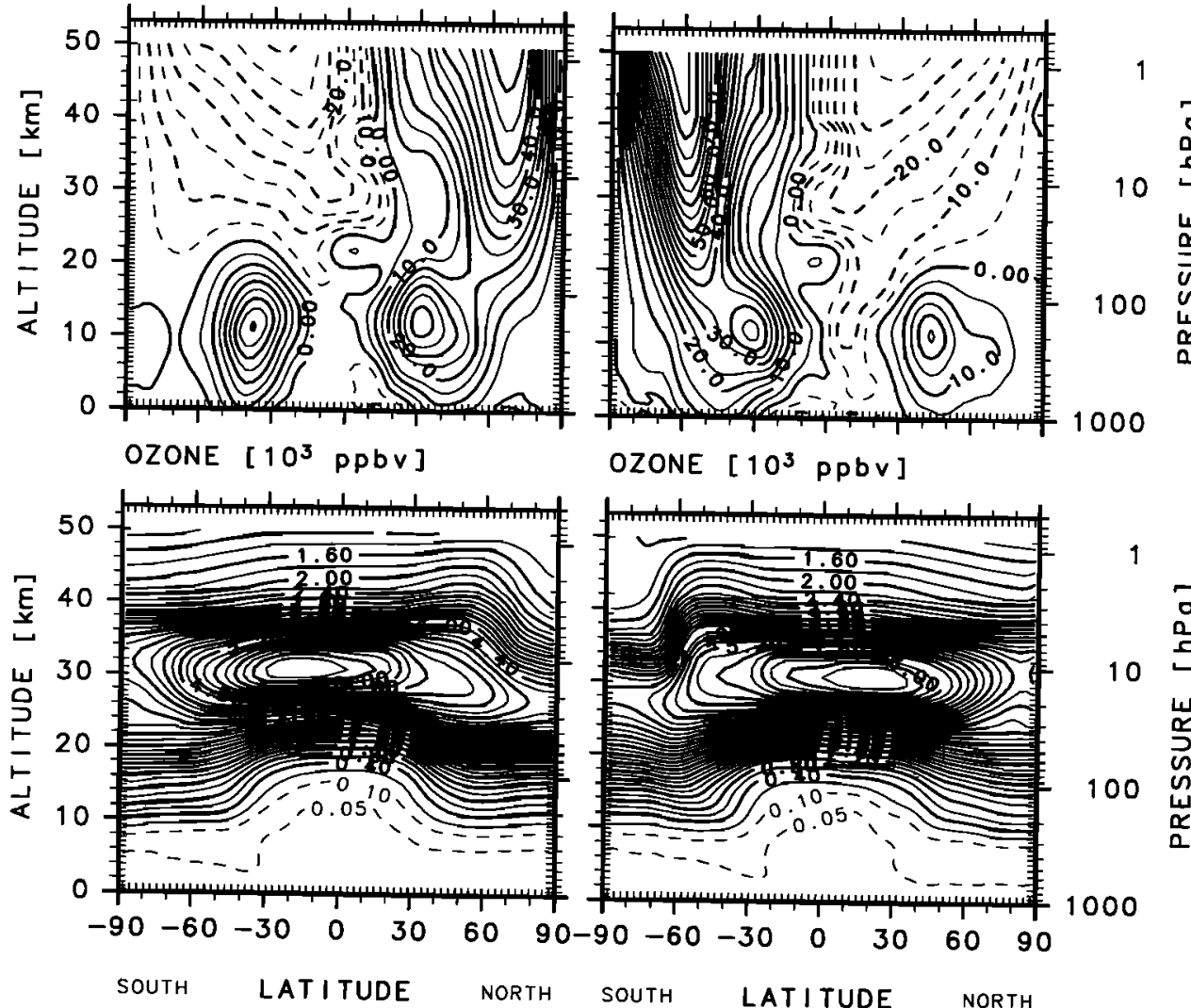

OZONE [ $10^{3}$ ppbv]

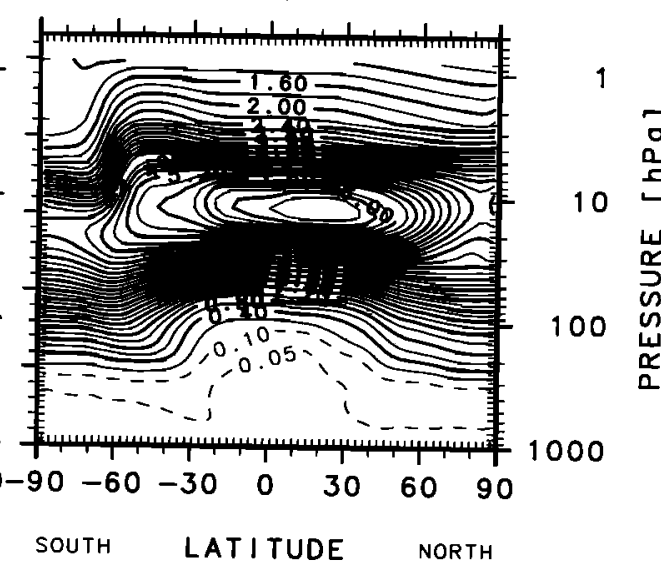

Figure 1. Zonal mean latitude-altitude distributions of (top) temperature, (middle) zonal wind, and (bottom) ozone mixing ratio for (left) January and (right) July of the fifteenth year. The contour intervals are $5 \mathrm{~K}$ for temperature, $5 \mathrm{~m} \mathrm{~s}^{-1}$ for zonal wind, and $0.2 \times 10^{3} \mathrm{ppbv}$ for ozone. Dashed lines for zonal wind represent westward winds. In the ozone panels, $0.1 \times 10^{3}$ and $0.05 \times 10^{3}$ ppbv lines are added.

for Atmospheric Research Community Climate Model (NCAR CCM2) at T42 [Boville, 1995], the tropical tropopause temperatures are $\sim 10 \mathrm{~K}$ less than the observations and $\sim 5 \mathrm{~K}$ less than NCAR CCM2 in both months, and the temperatures of the winter polar lower stratosphere, 25 to $30-\mathrm{km}$ altitudes, are $\sim 10-15 \mathrm{~K}$ less than the observations and $\sim 5 \mathrm{~K}$ less than NCAR CCM2 in both months. The separation between the midlatitude westerly jet and the polar night jet is well simulated in both months, but the polar night jet is a factor of $\sim 1.5$ stronger than the observations in January.
The model also simulated the basic characteristics of the ozone distribution qualitatively in all the months. Compared to the satellite ozone observations [McPeters et al., 1984], the altitudes where the maximum mixing ratio occurs are consistent except for the winter polar regions, but the maximum concentrations are $\sim 30-40 \%$ less than the observations in both months. However, the ozone distribution around the global tropopause is well simulated. Figure 2 shows the yearly-averaged longitude-altitude distribution of ozone at the equator $\left(1.3953^{\circ} \mathrm{N}\right)$. The ozone distribution does not show sig- 


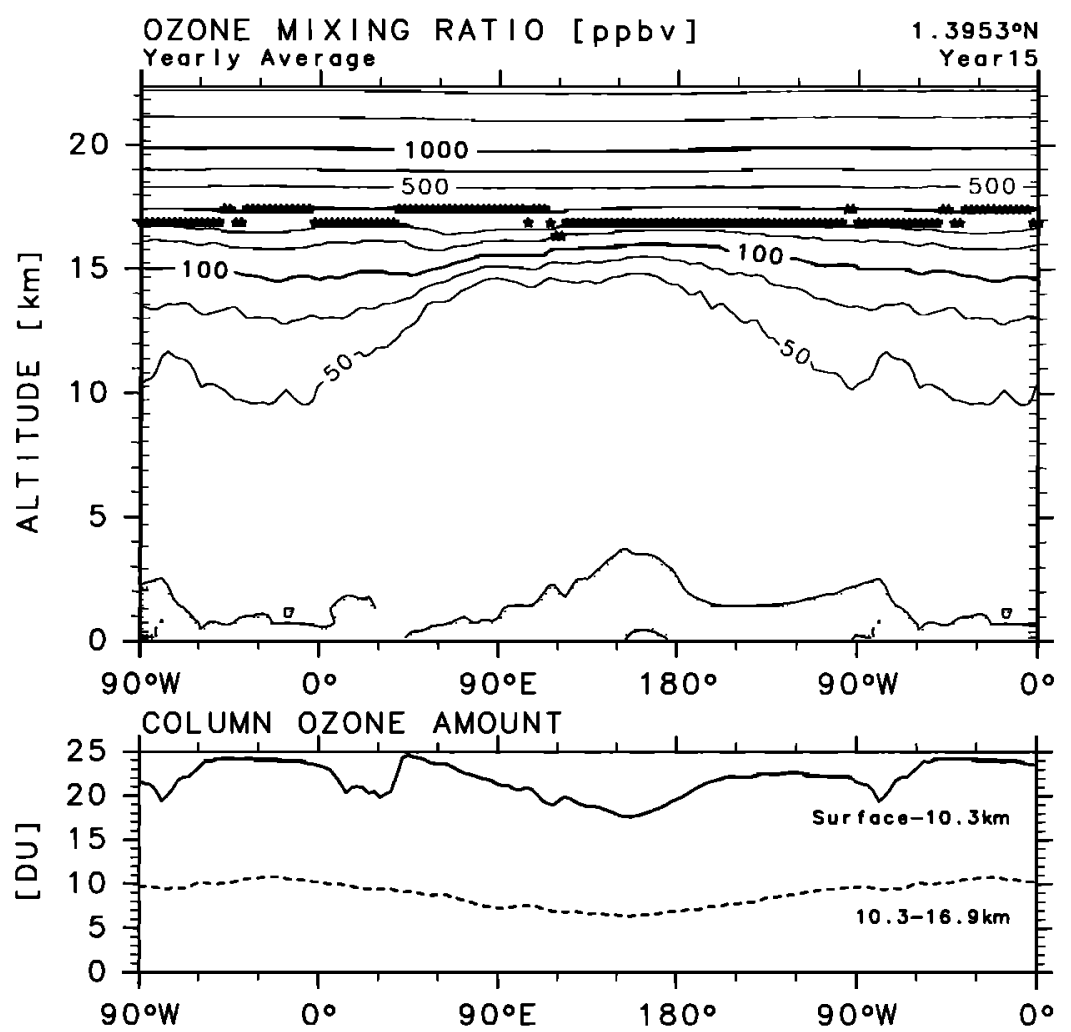

Figure 2. Yearly-averaged (top) longitude-altitude distribution of ozone mixing ratio and (bottom) longitudinal distribution of column ozone amounts in Dobson units (solid curve for surface to $10.3 \mathrm{~km}$ and dashed curve for $10.3-16.9 \mathrm{~km})$ at the equator $\left(1.3953^{\circ} \mathrm{N}\right)$ for the fifteenth year. The contour lines are $[1,1.5,2,3,5,7] \times 10^{n} \mathrm{ppbv}$, where $n=1 \sim 3$. The shaded regions in the top panel correspond to values of less than $30 \mathrm{ppbv}$. The location of the tropopause defined by the temperature minimum is indicated by stars. Note that the region $90^{\circ} \mathrm{W}-0^{\circ}$ is duplicated.

nificant longitudinal inhomogeneity in the lower stratosphere and at the tropopause defined by temperature minimum. There is virtually no longitudinal difference in the stratospheric column ozone as well (not shown). However, in the troposphere, the zonal wave number one structure, which was first found by satellite observations [e.g., Fishman et al., 1990; Shiotani, 1992; Shiotani and Hasebe, 1994; Ziemke et al., 1996], can be seen; the concentration is lower over the Indian Ocean and the western Pacific including the Indonesian maritime continent and higher over the rest of the tropics. The differences in column ozone amount between the western Pacific and the Atlantic are $\sim 5$ Dobson units (DU) in the 10.3 to $16.9-\mathrm{km}$ region and $\sim 6 \mathrm{DU}$ in the surface to $10.3-\mathrm{km}$ region, showing a comparable contribution of the upper troposphere and the lower troposphere to the wave one structure. These features are also basically true for all the monthly mean plots. As pointed out by Fujiwara et al. [2000], the upper tropospheric feature is consistent with the results of some ozonesonde observations in the tropics. Because the region over the Indian Ocean and the western Pacific corresponds to the area of active deep convection, the primary factor for this longitudinal inhomogeneity may be the convective transport of low-ozone air from the planetary boundary layer to the upper regions. The re- gions over South America and Africa are also convective regions, but the strength and zonal extent of the convection there are much smaller, affecting only the 50-ppbv contour line in the top panel of Figure 2. Note that the present model does not incorporate the biomassburning process which is a major ozone source in the real tropics [e.g., Fujiwara et al., 1999, 2000, and the references therein]. Therefore the tropical tropospheric zonal wave one structure would exist even in a world without biomass burning and would be caused by the longitudinal difference in convective transport.

As for the interannual variation of zonal wind in the equatorial lower stratosphere, the present model did not simulate any QBO-like oscillation during the 4-year integration period. The eastward wind region has stayed at 20 to $25-\mathrm{km}$ altitudes with only a slight downward phase motion ( $\left.<200 \mathrm{~m} \mathrm{month}^{-1}\right)$. However, Takahashi [1999] succeeded in simulating a realistic QBO-like oscillation using a T42, 60-layer CCSR/NIES GCM with the moist convective adjustment scheme. We made an independent experiment using his model except that the Arakawa-Schubert scheme was applied and found that the momentum flux by resolved-scale convectively generated gravity waves was insufficient to produce a QBOlike oscillation. A similar result that the wave generation strongly depends on the cumulus parameterization 
has been obtained for other GCMs (T. Horinouchi, private communication, 1999). It should be noted that in the real atmosphere, the eastward wind region exists in the equatorial lower stratosphere during about three

(a) OZONE MIXING RATIO [ppbv]

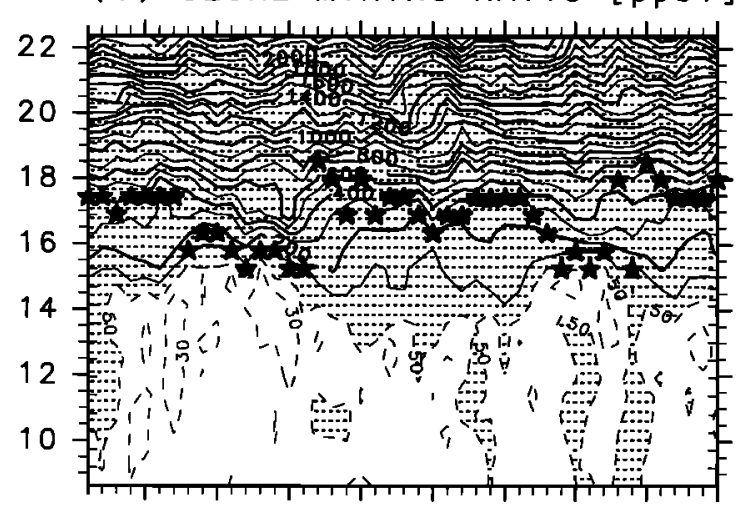

(b) ZONAL WIND $[\mathrm{m} / \mathrm{s}]$

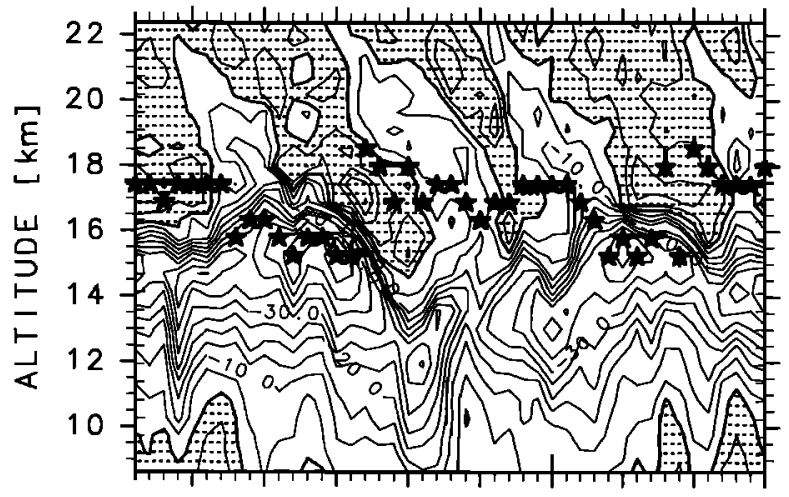

(c) SPECIF IC HUMIDITY [ $\mathrm{kg} / \mathrm{kg}]$

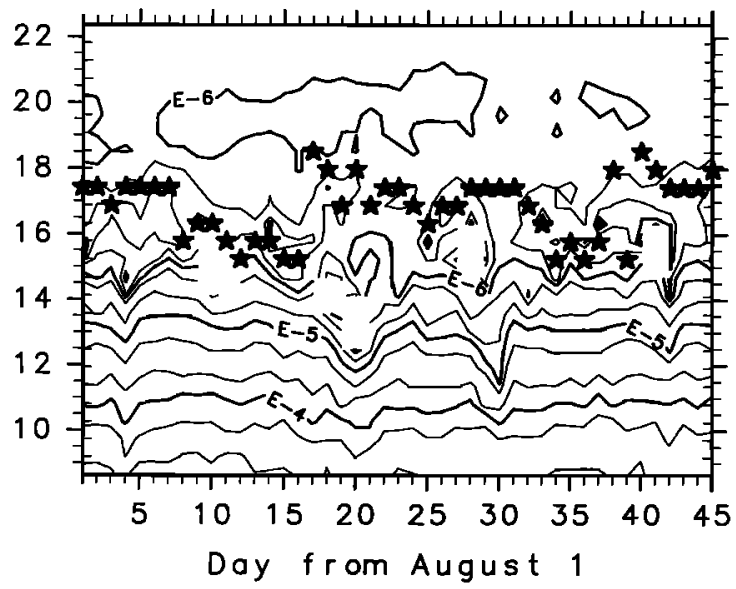

Figure 3. Time-altitude distributions of (a) ozone mixing ratio, (b) zonal wind, and (c) specific humidity from August 1 to September 15 of the fifteenth year between 9 and $22 \mathrm{~km}$ at $\left(1.3953^{\circ} \mathrm{N}, 70.312^{\circ} \mathrm{E}\right)$. The contour intervals for Figures $3 a$ and $3 b$ are 100 ppbv and $5 \mathrm{~m} \mathrm{~s}^{-1}$, respectively. Dashed lines for 30 and $50 \mathrm{ppbv}$ are added for Figure 3a. The shaded regions correspond to values of more than $50 \mathrm{ppbv}$ for Figure $3 \mathrm{a}$ and to regions of eastward wind for Figure 3b. The contour lines for Figure $3 c$ are $[1,2,5] \times 10^{n} \mathrm{~kg} \mathrm{~kg}^{-1}$, where $n=-8 \sim-3$. Negative values are omitted in Figure 3c. The location of the tropopause is indicated by stars in each panel. fourths of a cycle of QBO [e.g., Andrews et al., 1987, Figure 8.1]; thus the situation of the model atmosphere, the eastward wind at $20-25 \mathrm{~km}$, is not unrealistic for the present purpose.

\section{Case Study Over the Indian Ocean in the Northern Summer}

Several events similar to the one observed by Fujiwara et al. [1998] are found in the model results. In this section, a case obtained over the Indian Ocean in August-September of the fifteenth year is described and characterized in detail.

\section{1. "Observation" at a Station in the Model}

Figure 3 shows the variations of ozone mixing ratio, zonal wind, and specific humidity from August 1 (day 211) to September 15 (day 255) between 9 and $22 \mathrm{~km}$ at an equatorial station in the Indian Ocean (near Maldive Islands) in the model. Between August 8 and 16, the tropopause altitude became lower, and downward ozone displacement was seen in the lower stratosphere. Following a jump of the tropopause on August 17, stratospheric ozone moved into the upper tropospheric region. The stratospheric influence in the upper troposphere had continued until early September. During the "observation" period, zonal wind oscillation with a period of $\sim 14$ days (August 7 to 21 , at $17 \mathrm{~km}$ ) was observed. The tropopause jump on August 17 corresponded to an abrupt zonal wind change from westward to eastward, in other words, a strong eastward wind shear with a downward phase propagation of $\sim-6.9 \times 10^{-3} \mathrm{~m} \mathrm{~s}^{-1}$ (from $16.5 \mathrm{~km}$ on August 15 to $13.5 \mathrm{~km}$ on August 20). Another similar disturbance with similar ozone variation was seen in September. These features are qualitatively similar to the observation by Fujiwara et al. [1998] (see their Figure 3 and Plate 1). Specific humidity around the tropopause also showed a corresponding variation to ozone and meteorological parameters: During August 8-16, the upper troposphere was relatively wet with lower ozone concentrations, and after the tropopause jump on August 17, the upper troposphere was relatively dry with higher ozone concentrations, being associated with the stratospheric air mass intrusion.

Figure 4 shows the variations of temperature between 12 and $20 \mathrm{~km}$, vertical wind and liquid water content between the surface and $20 \mathrm{~km}$, and surface precipitation for the same period at the same station as in Figure 3. Vertical wind, $w$, was estimated from an approximate relation,

$$
w \sim-(1 / g)(R T / P)(d P / d t),
$$

where $g$ is the gravitational acceleration, $R$ is the gas constant for dry air, $T$ is air temperature, and $d P / d t$ is the vertical pressure velocity. During August 5-15, about 10 to a few days before the tropopause jump, active convections had occurred, being evidenced by 
(a) TEMPERATURE [K]

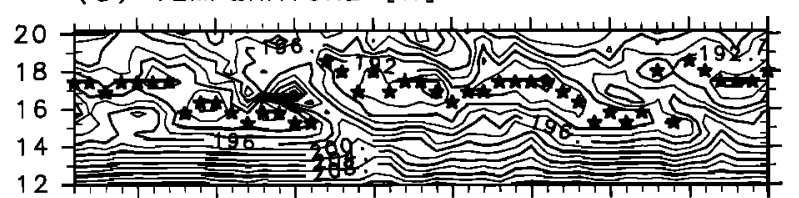

(b) VERTICAL WIND $[\mathrm{m} / \mathrm{s}]$

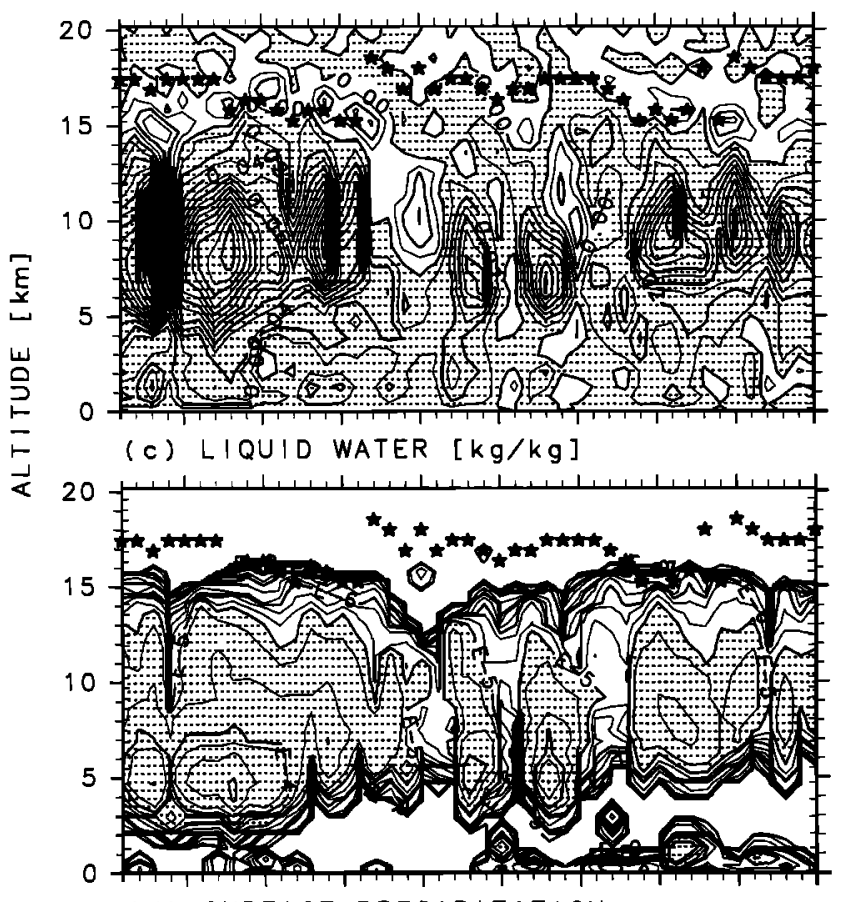

(d) SURFACE PRECIPITATION

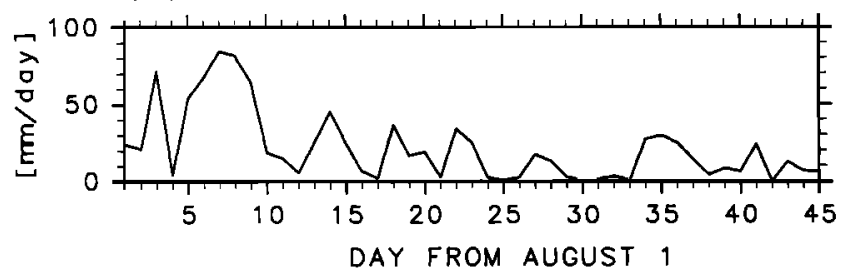

Figure 4. Time-altitude distributions of (a) temperature between 12 and $20 \mathrm{~km}$, (b) vertical wind, and (c) liquid water content between the surface and $20 \mathrm{~km}$, and (d) time distribution of surface precipitation in $\mathrm{mm} \mathrm{d}^{-1}$ for the same period at the same station as in Figure 3. The contour intervals are $2 \mathrm{~K}$ for Figure $4 \mathrm{a}$ and $1 \times 10^{-2}$ $\mathrm{m} \mathrm{s}^{-1}$ for Figure $4 \mathrm{~b}$. The contour lines for liquid water are $[1,2,5] \times 10^{n} \mathrm{~kg} \mathrm{~kg}^{-1}$, where $n=-9 \sim-2$. The shaded regions correspond to those of upward wind for Figure $4 \mathrm{~b}$ and those of more than $10^{-5} \mathrm{~kg} \mathrm{~kg}^{-1}$ for Figure $4 \mathrm{c}$. The location of the tropopause is indicated by stars in Figures 4a-4c.

the strong upward winds and much liquid water in the troposphere and much precipitation at the surface (see also Figure 3c). At this active convection phase, the tropopause became colder and lower with a downward wind layer of $2 \mathrm{~km}$ thickness. While the lower stratosphere was adiabatically warmed by downward displacement evidenced by the ozone variation, the tropopause was diabatically cooled mainly by the radiative process above deep convections (especially, the emission of infrared radiation to space by clouds and water vapor) rather than the evaporation process. (At the tropopause level, the contribution of the evaporation/condensation to the diabatic cooling/heating is negligible compared to that of the radiative process because of the small water amount.) The existence of a thin downward wind layer around the colder tropopause indicates the contribution of such a diabatic process. The correspondence of the colder tropopause, downward winds around the tropopause, and active convections has also been observed in the real atmosphere, though the temporal/spatial scale may be different [e.g., Johnson and Kriete, 1982, Figure 3; Balsley et al., 1988; Gage et al., 1991; Sherwood, 2000]. At the time of the tropopause jump on August 17 and until a week after, the convective activity became weak, and the downward wind region moved downward into the troposphere; it is these downward winds that transported dry, ozone-rich stratospheric air into the upper troposphere. Therefore we can conclude that during the passage of such a disturbance, the tropopause region maintains its dryness: Diabatic cooling processes and the thin downward wind layer above active convections prevent the lower stratosphere from developing excess water, and large-scale downward winds at the nonconvective phase transport the dry, ozone-rich stratospheric air into the upper troposphere. This would be one of the important processes controlling the stratospheric water vapor budget.

\subsection{Spatial Structures}

In this section, the longitudinal and latitudinal structures of the case "observed" over the modeled Indian Ocean are investigated to characterize the nature of the disturbance. Figure 5 shows the equatorial longitudealtitude distributions of ozone mixing ratio by a 2day step from August 15 to 21. Note that on August 17, a tropopause jump was observed near Maldive Islands $\left(70.312^{\circ} \mathrm{E}\right.$; Figures 3 and 4$)$. An ozone downward displacement region coinciding with a tropopause jump/break appeared over the eastern Africa/the Indian Ocean $\left(30^{\circ}-90^{\circ} \mathrm{E}\right)$ on August 9-11 (not shown) and started to propagate eastward on August 13-15, and the tropopause break point passed over the Indian Ocean and reached the Indonesian maritime continent on August 19-21. After that, the ozone vertical displacement had become much smaller. Over the Indian Ocean, the longitudinal scale of the ozone enhancement in the upper troposphere was $\sim 4400 \mathrm{~km}\left(30^{\circ}-70^{\circ} \mathrm{E}\right.$, at $16 \mathrm{~km}$ on August 15), and the downward displacement of the 100-ppbv ozone isoline was $\sim 3 \mathrm{~km}$. Figure 6 shows the equatorial longitude-altitude distributions of zonal wind for the same period as in Figure 5. A pair of eastward wind and westward wind anomalies exactly corresponded to the ozone-enhanced region described above, with the eastward wind shear line just at the tropopause break. The horizontal wavelength, $\lambda_{x}$, is $\sim 10,000 \mathrm{~km}\left(20^{\circ}-110^{\circ} \mathrm{E}\right.$, at $16 \mathrm{~km}$ on August 15), and 


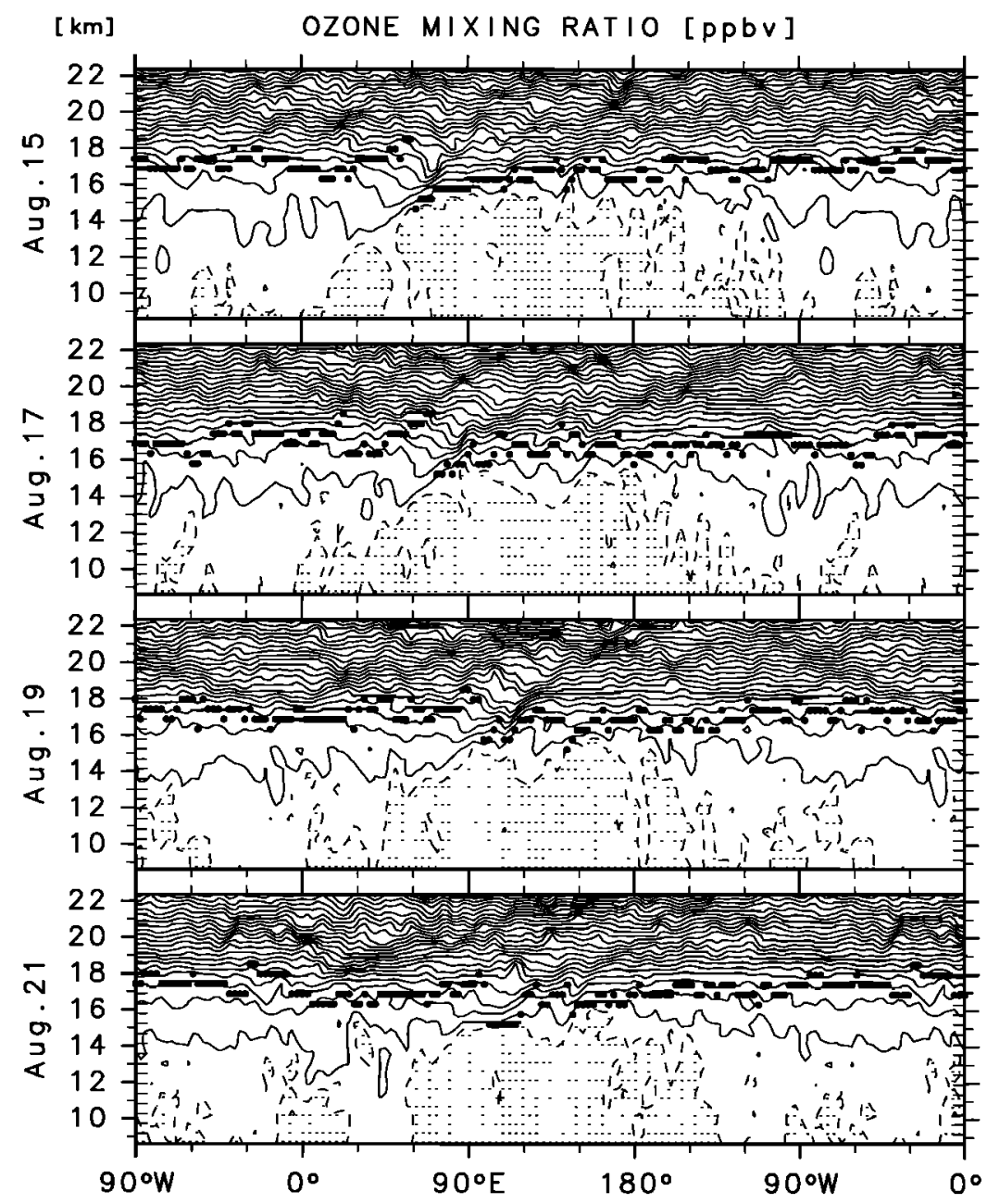

Figure 5. Longitude-altitude distributions of ozone mixing ratio between 9 and $22 \mathrm{~km}$ at the equator $\left(1.3953^{\circ} \mathrm{N}\right)$ on August 15, 17, 19, and 21 of the fifteenth year. The contour interval is $100 \mathrm{ppbv}$. Dashed lines are added for $50 \mathrm{ppbv}$. The shaded regions correspond to those of less than 50 ppbv. The location of the tropopause is indicated by solid circles. Note that the region $90^{\circ} \mathrm{W}-0^{\circ}$ is duplicated.

the vertical wavelength, $\lambda_{z}$, is $\sim 10 \mathrm{~km}$ (between the two zero-zonal-wind lines at 10 and $20 \mathrm{~km}$, at $55^{\circ} \mathrm{E}$ on August 15), although there existed only one full wavelength. The zonal phase velocity, $c^{(x)}$, is estimated as $\sim 8.3 \mathrm{~m} \mathrm{~s}^{-1}$ from the period of 14 days in Figure $3 \mathrm{~b}$ and $\lambda_{x}$, which is consistent with the motion of the eastward wind shear line in Figure 6 . The amplitude of the wave, $u_{\text {amp }}$, and the background zonal wind for the wave, $\bar{u}$, at $16 \mathrm{~km}$ on August 15 are estimated as $\sim 35 \mathrm{~m} \mathrm{~s}^{-1}$ and $\sim-15 \mathrm{~m} \mathrm{~s}^{-1}$, respectively, from the eastward wind maximum of $\sim 20 \mathrm{~m} \mathrm{~s}^{-1}$ at $35^{\circ} \mathrm{E}$ and the westward wind maximum of $\sim 50 \mathrm{~m} \mathrm{~s}^{-1}$ at $75^{\circ} \mathrm{E}$. Because the disturbance has some characteristics of the equatorial Kelvin wave (e.g., eastward propagation and vertical displacement), we calculate $\lambda_{z}$ using the dispersion relation of the equatorial Kelvin wave,

$$
\omega-k \bar{u}=-N k / m,
$$

where $\omega$ is the frequency, $k$ is the zonal wave number, $N$ is the buoyancy frequency (or the Brünt-Väisälä fre- quency), and $m$ is the vertical wave number. Using $\omega \equiv k c^{(x)}, \lambda_{z}$ is written as

$$
\lambda_{z} \equiv 2 \pi /|m|=2 \pi\left|c^{(x)}-\bar{u}\right| / N .
$$

Using the estimated values for $c^{(x)}$ and $\bar{u}$ together with $N=1.0 \times 10^{-2} \mathrm{~s}^{-1}$ (the average value for $13.5 \mathrm{~km}$ altitude at $\left(1.3953^{\circ} \mathrm{N}, 70.312^{\circ} \mathrm{E}\right)$ from August 1 to September 15) and $N=2.2 \times 10^{-2} \mathrm{~s}^{-1}$ (the average value above $18 \mathrm{~km}$ altitude at $\left(1.3953^{\circ} \mathrm{N}, 70.312^{\circ} \mathrm{E}\right)$ from August 1 to September 15), $\lambda_{z}$ is calculated as $15 \mathrm{~km}$ and $6.7 \mathrm{~km}$, respectively. The $\lambda_{z} \sim 10 \mathrm{~km}$, estimated from Figure 6, is between these two values. (It should be noted that the average $N$ profile has a large positive vertical gradient from 10 to $18 \mathrm{~km}$ and stays nearly constant in the stratosphere.)

Figure 7 shows the meridional cross section of ozone over Africa $\left(33.75^{\circ} \mathrm{E}\right)$ on August 15 with some isentropic surfaces superimposed. The ozone enhancement in the equatorial upper troposphere has a latitudinal extent of $\pm 15^{\circ}$ at most with an inverse Gaussian-like 


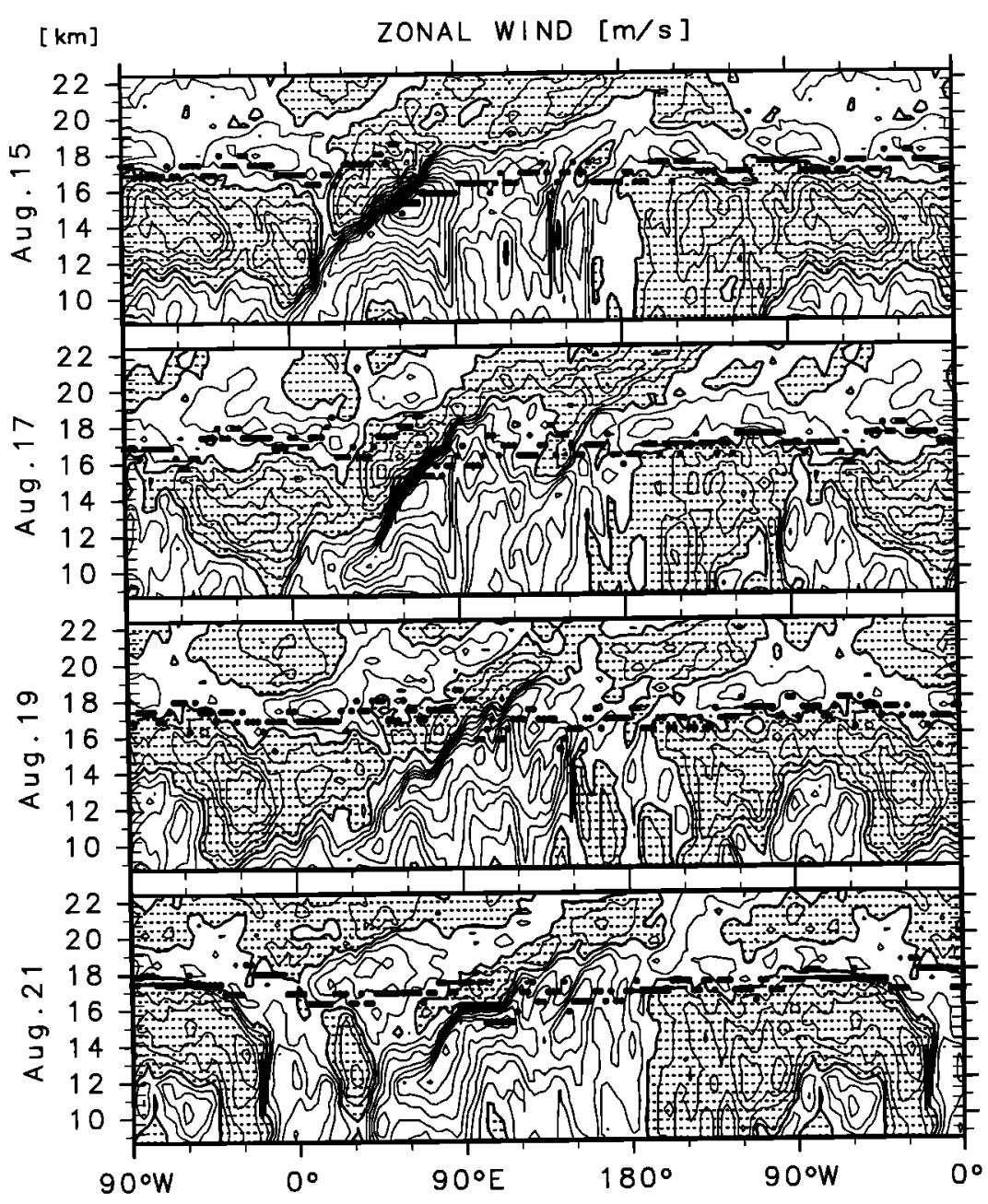

Figure 6. Same as Figure 5 but for zonal wind. The contour interval is $5 \mathrm{~m} \mathrm{~s}^{-1}$. The shaded regions correspond to those of eastward wind.

structure (e.g., 100-ppbv curve) and is well separated from any quasi-horizontal transport within the "middle world" [e.g., Chen, 1995; Holton et al., 1995] (see the $350-\mathrm{K}$ surface). Note that the tropical and subtropical lower troposphere is influenced by tropopause foldings at midlatitudes (see the $330-\mathrm{K}$ surface).

One of the important characteristics of the equatorial Kelvin wave is that it does not have any substantial meridional-wind component (see Figures 4-8 of Matsuno [1966] for the relation between pressure and velocity fields of various equatorial waves). Figure 8 shows the horizontal wind vectors on $104.98 \mathrm{hPa}$ on August 15 and 17. A pair of weak eastward wind and strong westward wind anomalies are propagating eastward along the equator at $30^{\circ}-120^{\circ} \mathrm{E}$ longitudes, being without substantial meridional winds. However, there may be some interactions between the equatorial disturbance and the subtropical anticyclonic eddies in both hemispheres (outside the $10^{\circ} \mathrm{S}-10^{\circ} \mathrm{N}$ region). The largescale anticyclonic circulation at $0^{\circ}-140^{\circ} \mathrm{E}$ in the northern subtropics corresponds to the Tibetan High which develops during the northern summer. At $10^{\circ}-20^{\circ} \mathrm{N}$, the tropical branch of the Tibetan High results in the formation of the tropical easterly jet stream confined in the 100 to $200-\mathrm{hPa}$ levels [e.g., Koteswaram, 1958]. The anticyclonic eddy west of Australia is transient.

\subsection{Kelvin Wave-Circulation Cell System}

As described in the previous section, the disturbance which has caused the variations of ozone and water around the equatorial tropopause has the major properties of the equatorial Kelvin wave [cf., Parker, 1973]: (1) It is limited within $\pm 15^{\circ}$ latitudes (e.g., Figure 7); (2) it propagates eastward relative to the background zonal wind (Figure 6); (3) it has a zonal wind component but no substantial meridional wind component (Figure 8); (4) it is symmetrical about the equator with a Gaussian-like structure (e.g., Figure 7); (5) it satisfies the dispersion relation of the theoretical equatorial Kelvin wave (equations (2) and (3)); (6) its positive temperature phase leads its eastward wind phase by a quarter cycle at a given height (Figures $3 \mathrm{~b}$ and $4 \mathrm{a}$ ); and (7) its positive geopotential phase corresponds to its eastward wind phase at a given height (not shown). 


\section{OZONE MIXING RATIO [ppbV] $33.750^{\circ} \mathrm{E}$}

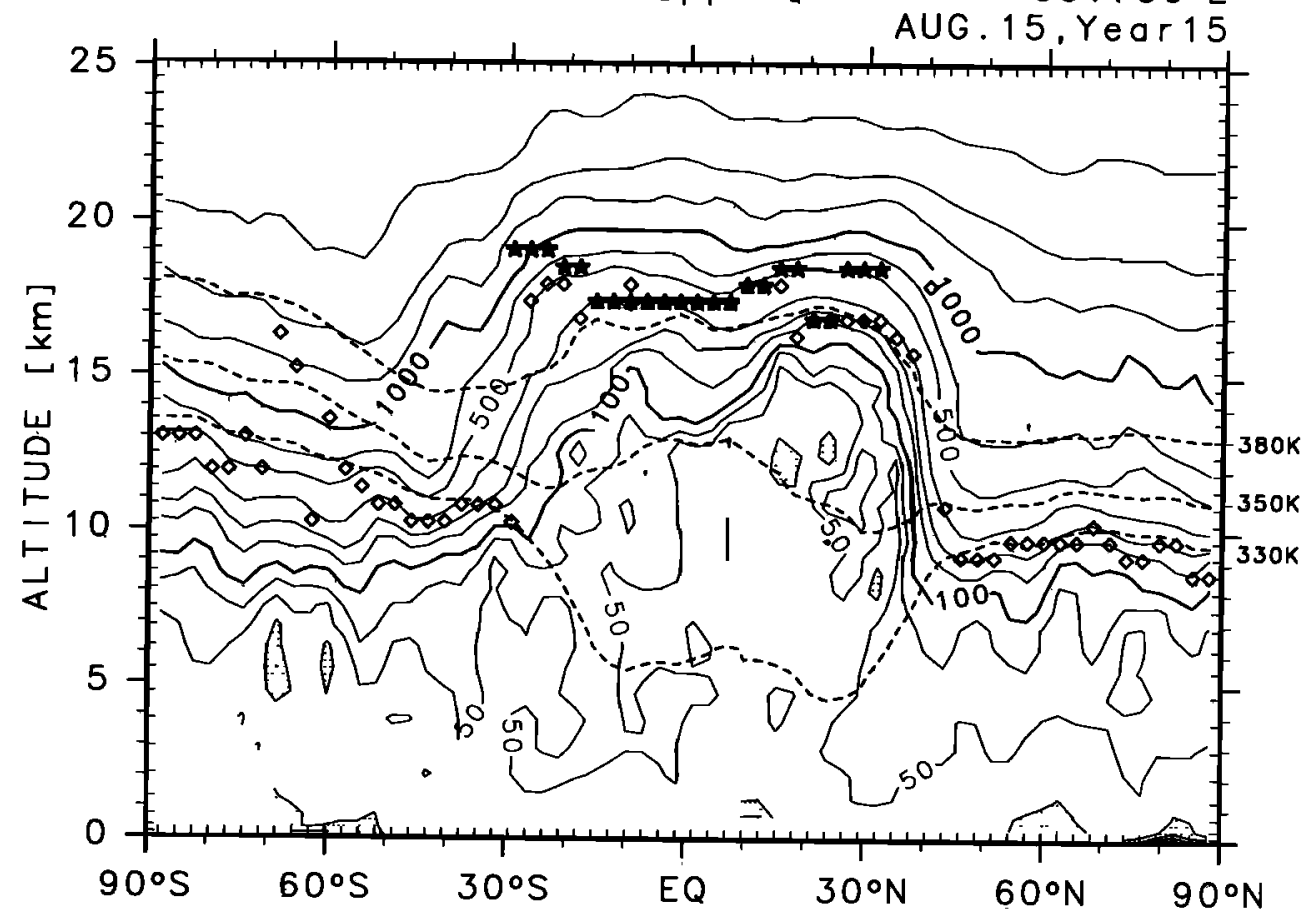

Figure 7. Latitude-altitude distribution of ozone mixing ratio at $33.75^{\circ} \mathrm{E}$ on August 15 of the fifteenth year. The contour lines are $[1,1.5,2,3,5,7] \times 10^{n} \mathrm{ppbv}$, where $n=1 \sim 3$. The shaded regions correspond to those of less than $30 \mathrm{ppbv}$. The location of the tropopause defined by the temperature minimum is indicated by stars only within $\pm 30^{\circ}$ latitudes, and that based on the World Meteorological Organization (WMO) definition [e.g., Holton et al., 1995] is indicated by open diamonds globally. Isentropic surfaces for $330 \mathrm{~K}, 350 \mathrm{~K}$, and $380 \mathrm{~K}$ are indicated by dashed lines.
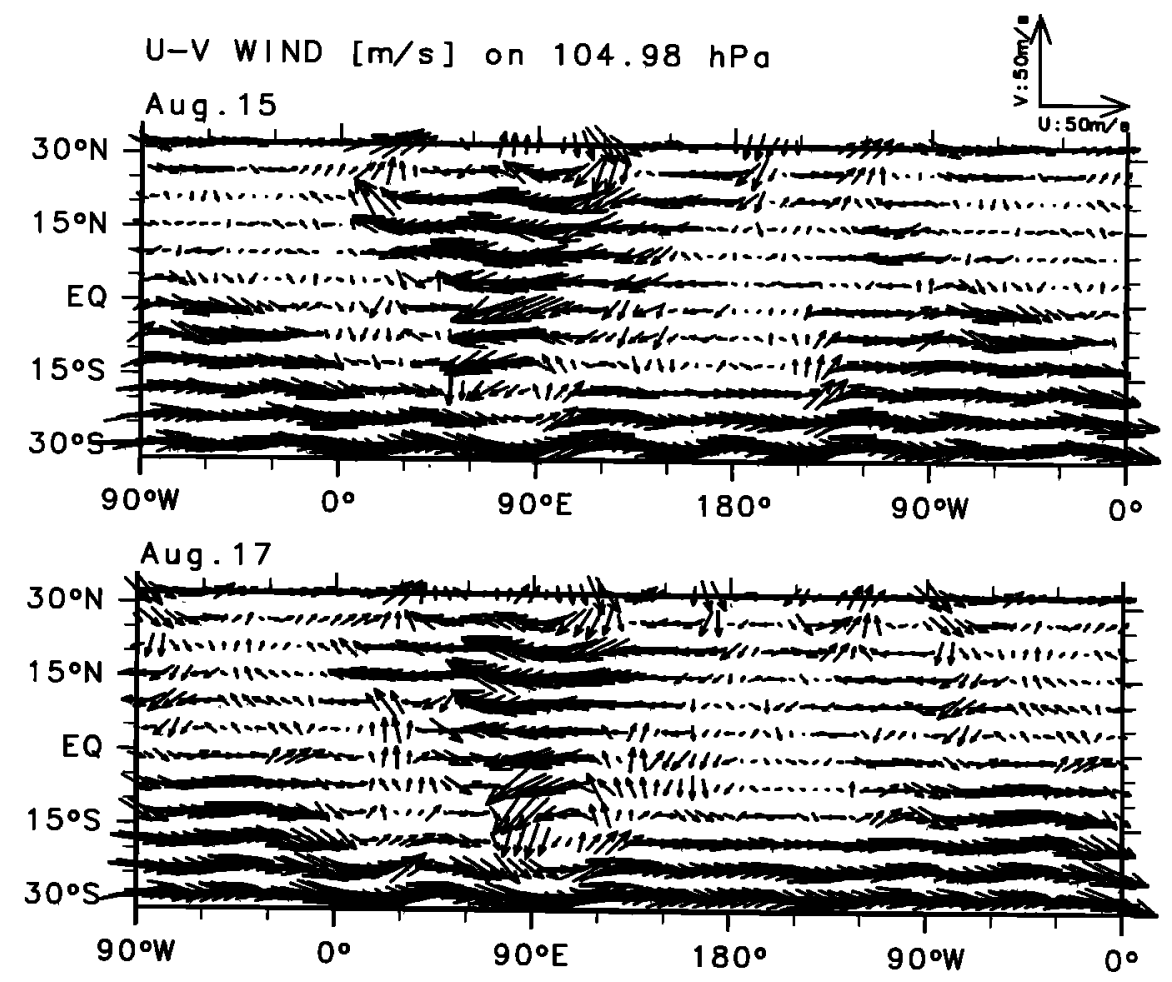

Figure 8. Horizontal wind vector maps on $104.98 \mathrm{hPa}(15.78 \mathrm{~km})$ on August 15 and 17 of the fifteenth year. The amount of the vectors is reduced to a fourth. Note that the region $90^{\circ} \mathrm{W}-0^{\circ}$ is duplicated. 
Table 1. Summary of Some Parameters Predicted by the Linear Theory of the Equatorial Kelvin Wave and Estimated Directly From the Figures Around August 15 ( $m$ is Calculated From $\lambda_{z}=10 \mathrm{~km}$ )

\begin{tabular}{|c|c|c|c|c|}
\hline Parameter & Linear Theory & $N=1.0 \times 10^{-2}$ & $N=2.2 \times 10^{-2}$ & Estimation \\
\hline Vertical phase velocity, $c^{(z)}, \mathrm{m} \mathrm{s}^{-1}$ & $-k c^{(x)}\left(c^{(x)}-\bar{u}\right) N^{-1}$ & $-1.2 \times 10^{-2}$ & $-5.5 \times 10^{-3}$ & $-6.9 \times 10^{-3}$ \\
\hline Vertical displacement, $2 \zeta_{0}, \mathrm{~km}$ & $2 u_{\mathrm{amp}} N^{-1}$ & 7.0 & 3.2 & 3 \\
\hline Latitudinal extent, $L_{y}, \mathrm{~km}$ & $2\left(2 N \beta^{-1}|m|^{-1}\right)^{1 / 2}$ & $2.4 \times 10^{3}$ & $3.5 \times 10^{3}$ & $<3 \times 10^{3}$ \\
\hline Vertical group velocity, $c_{g}^{(z)}, \mathrm{m} \mathrm{s}^{-1}$ & $\mathrm{Nkm}^{-2}$ & $1.6 \times 10^{-2}$ & $3.5 \times 10^{-2}$ & --- \\
\hline
\end{tabular}

Therefore the disturbance should be regarded as the equatorial Kelvin wave.

Table 1 summarizes some parameters predicted by the linear theory for the equatorial Kelvin wave [e.g., Andrews et al., 1987; Fujiwara et al., 1998] and estimated directly from the figures. As for the vertical phase velocity, vertical displacement, and latitudinal extent, the theoretical prediction and the estimation are in reasonable agreement. However, the vertical group velocity seems very slow in Figure 6; the wave packet remains around the tropopause at least during the 6day period, while the theory for $N=2.2 \times 10^{-2} \mathrm{~s}^{-1}$ predicts that the tropopause-level packet on August 15 should reach $22 \mathrm{~km}$ altitude by August 17. This discrepancy may imply the existence of a continuous heat source in the troposphere for the tropopause-level wave or insufficient vertical resolution of the model.

Plate 1 shows the longitude-altitude distributions of ozone mixing ratio, liquid water, and $u-w$ vector, where $u$ is zonal wind, together with the surface precipitation at the equator on August 15. A large-scale deep convection with a well-organized zonal circulation cell is present over the Indian Ocean, being coupled with the Kelvin wave around the tropopause. The whole system has a zonal extent of $\sim 10,000 \mathrm{~km}\left(30^{\circ}-120^{\circ} \mathrm{E}\right)$ and the convective circulation cell moves eastward together with the tropopause Kelvin wave down to the Indonesian maritime continent (not shown). At the western part of the top of this cell $\left(30^{\circ}-60^{\circ} \mathrm{E}\right)$, a dry, ozone-rich stratospheric air mass is moving downward into the upper troposphere. At the eastern part of the top of this cell, on the other hand, a wet, ozone-poor lower tropospheric air mass has approached the tropopause but never entered into the stratosphere due to the specific flow pattern and cold trap explained in section 4.1. This convective circulation cell may correspond to MJO in the real atmosphere [Madden and Julian, 1972, 1994] or a "convectively coupled Kelvin wave" as a whole [e.g., Wheeler and Kiladis, 1999; Wheeler et al., 2000, Figure 7]. We interpret that the large-scale convective cell took the form of the equatorial Kelvin wave at its top because of the increase of the background static stability and caused the variations of ozone and water around the tropopause. It should be noted that over Indonesia (near $150^{\circ} \mathrm{E}$ ), there is another strong convective region with much more precipitation, but that this does not cause a large-scale tropopause deformation.

Finally, we discuss the breaking of the Kelvin wave of this case. The wave has a large amplitude, $u_{\mathrm{amp}} \sim 35$ $\mathrm{m} \mathrm{s}^{-1}$ on August 15 (Figure 6), and a rapid zonal wind change from westward to eastward at a station (Figure 3b). Such large-amplitude Kelvin waves at the tropopause have been observed in the real atmosphere [e.g., Nishi and Sumi, 1995]. For the eastward moving gravity waves, including Kelvin waves, if the amplitude of the zonal wind component is comparable to the intrinsic zonal phase velocity of the wave, that is, $u_{\text {amp }} \approx c^{(x)}-\bar{u}$, the wave breaking (hence vertical air mixing) is expected at least at the maximum eastward wind phase (see section 4.2 of Fujiwara et al. [1998]). As $c^{(x)} \sim 8.3 \mathrm{~m} \mathrm{~s}^{-1}$ and $\bar{u} \sim-15 \mathrm{~m} \mathrm{~s}^{-1}$ on August 15 , the breaking condition is satisfied so that the consequent air mixing would contribute to irreversible transport to some extent. At the same time, this wave is dissipating during its propagation (Figure 6) partly due to this breaking process. Figure 9 shows the distribution of vertical diffusion coefficient for minor constituents on August 15. The diffusion coefficient is clearly enhanced nearly at the eastward wind phase (compare this with Figure 6 (top panel)). There was another enhancement in association with the convectively generated gravity wave over Indonesia $\left(140^{\circ}-170^{\circ} \mathrm{E}\right)$. It should be noted that the isentropic and material surfaces should become nearly vertical at the enhancement of vertical diffusion; this effect can be seen in the ozone distribution (Figures $3 \mathrm{a}$ and 5 and Plate 1a).

\section{Seasonal and Longitudinal Characteristics}

In this section, seasonal and longitudinal characteristics of the activity of large-scale disturbances at the equatorial tropopause are investigated. Plate 2 is the time-longitude distribution of ozone at the equatorial tropopause in the fifteenth year. Eastward propagating signals are found to be dominant. There are four characteristics, which are also common in the other three years of the experiment.

1. The most remarkable region and season are the $30^{\circ}-120^{\circ} \mathrm{E}$ longitudes, from eastern Africa through the 
Indian Ocean to western Indonesia, during the northern summer through autumn. These disturbances have large-amplitude, slower-moving natures with a typical zonal phase velocity of $\sim 8 \mathrm{~m} \mathrm{~s}^{-1}$ and a typical zonal scale of $\sim 10,000 \mathrm{~km}$. The August case investigated in section 4 is included in this category.

2. The second remarkable region and season are over Indonesia during the northern winter through spring. Eastward moving signals which are different from those in category 1 are present over $90^{\circ}-150^{\circ} \mathrm{E}$ during January-May.

3. Around the $180^{\circ}$ longitude and in the eastern Pacific, we see only weak signals, although the western $\mathrm{Pa}$ cific $\left(150^{\circ} \mathrm{E}\right.$ to $\left.180^{\circ}\right)$ is the region where the strongest precipitation occurs throughout the year in this model. Sometimes an ozone signal comes from the west, with a larger typical zonal phase velocity (e.g., $\sim 20 \mathrm{~m} \mathrm{~s}^{-1}$ ), and propagates globally (see the case in October, for example).

4. Over South America and the Atlantic, the $90^{\circ} \mathrm{W}$ $0^{\circ}$ longitudes, some signals are seen.

As shown in section 4, the disturbances in category 1 have well-organized convective circulation cells in the troposphere. The development of the tropospheric cell may be related to the existence of the summer monsoon circulation, which develops over south Asia in this season, intensifying the upper tropospheric tropical easterly jet over the tropical Indian Ocean (see Figure 8). Such a background zonal wind condition, together with a moisture supply, may be the main factor for largescale eastward moving disturbances to appear periodically along the equator. Wang and Xie [1997] simulated the northern summer ISO in the eastern hemisphere (an eastward propagating component at the equator and off-equatorial westward propagating ones) under a climatological July condition and discussed the detailed processes for its development and maintenance. Also, the high mountains in equatorial Africa may play a role in triggering these disturbances.

There are also some globally propagating signals as described in category 3. For the October case, similar analyses to those in section 4 show that this can also be regarded as an equatorial Kelvin wave. Similar to the case in section 4, the vertical group velocity is apparently much smaller than the linear theory prediction. The existence of a continuous heat source in the troposphere, moving with the tropopause-level disturbance, is one of the possible causes, as noted in section 4.3. However, the corresponding signal is unclear in liquid water content, especially in the western hemisphere, and also in surface precipitation. (Note that the eastward moving precipitation signal corresponding to the case in section 4 was also unclear even over the Indian Ocean.) Wheeler and Kiladis [1999] showed globally propagating "convectively coupled Kelvin waves" in the troposphere in the outgoing longwave radiation (OLR) anomaly field by using a filtering technique (see their Figures 8 and 9), though the signals over the eastern Pacific are generally very weak. However, such a weak heat source in the troposphere might be enough to maintain the tropopause-level wave propagating across the eastern Pacific.

In the real atmosphere, the $100-\mathrm{hPa}$ temperatures along the equator have large interannual variability associated with, for example, the El Niño-Southern Oscillation (ENSO), whereas the present model incorporates a climatological annual cycle of SST. Because the year 1996 was a normal (or weak La Niña) year, let us compare the model result with the $100-\mathrm{hPa}$ temperature data of the European Centre for Medium-Range Weather Forecasts (ECMWF) global analysis data in 1996. Plate 3 shows the time-longitude distributions of the equatorial $\sim 100-\mathrm{hPa}$ temperatures of the model and ECMWF in 1996. Considering the model's bias described in section 3 , we added $2 \mathrm{~K}$ to the GCM's field. Both panels are in reasonable agreement in terms of both general distribution and variability; the equatorial $\sim 100-\mathrm{hPa}$ temperature is on average lower during the northern winter and over the date line, and large-amplitude, slower, eastward moving signals are seen over the Indian Ocean during the northern summer through autumn. It should be noted that the warm anomalies of the eastward moving signals correspond to the dry, ozone-rich air masses transported from the stratosphere (e.g., Plate 1). At these warm phases, the air temperature increases adiabatically and the water vapor concentration decreases due to the dry air transport to make the local air unsaturated. This means that the method of Newell and Gould-Stewart [1981] and Dessler [1998], which assumes implicitly that the tropical tropopause air is always saturated, will overestimate the water vapor concentration at the tropopause [Vömel and Oltmans, 1999]. The present study suggests that when and where the large-scale gravity waves such as Kelvin waves are dominant, only their cold phases should be chosen to estimate the water vapor concentration around the tropopause because the air would be nearly saturated only at the cold phases and because the water vapor mixing ratio just above the tropopause would remain nearly constant during the passage of such waves.

\section{Concluding Remarks}

We investigated the large-scale disturbances which cause the variations of minor constituents around the equatorial tropopause by using the CCSR/NIES GCM. A case over the Indian Ocean in the northern summer, which resembles the observed case by Fujiwara et al. [1998], was described and characterized in detail. The tropopause-level disturbance had the characteristics of the equatorial Kelvin wave whose zonal phase velocity was $\sim 8.3 \mathrm{~m} \mathrm{~s}^{-1}$ and whose horizontal and vertical wavelengths are $\sim 10,000 \mathrm{~km}$ and $\sim 10 \mathrm{~km}$, respectively, being 


\section{(a) OZONE MIXING RATIO [ppbv]}
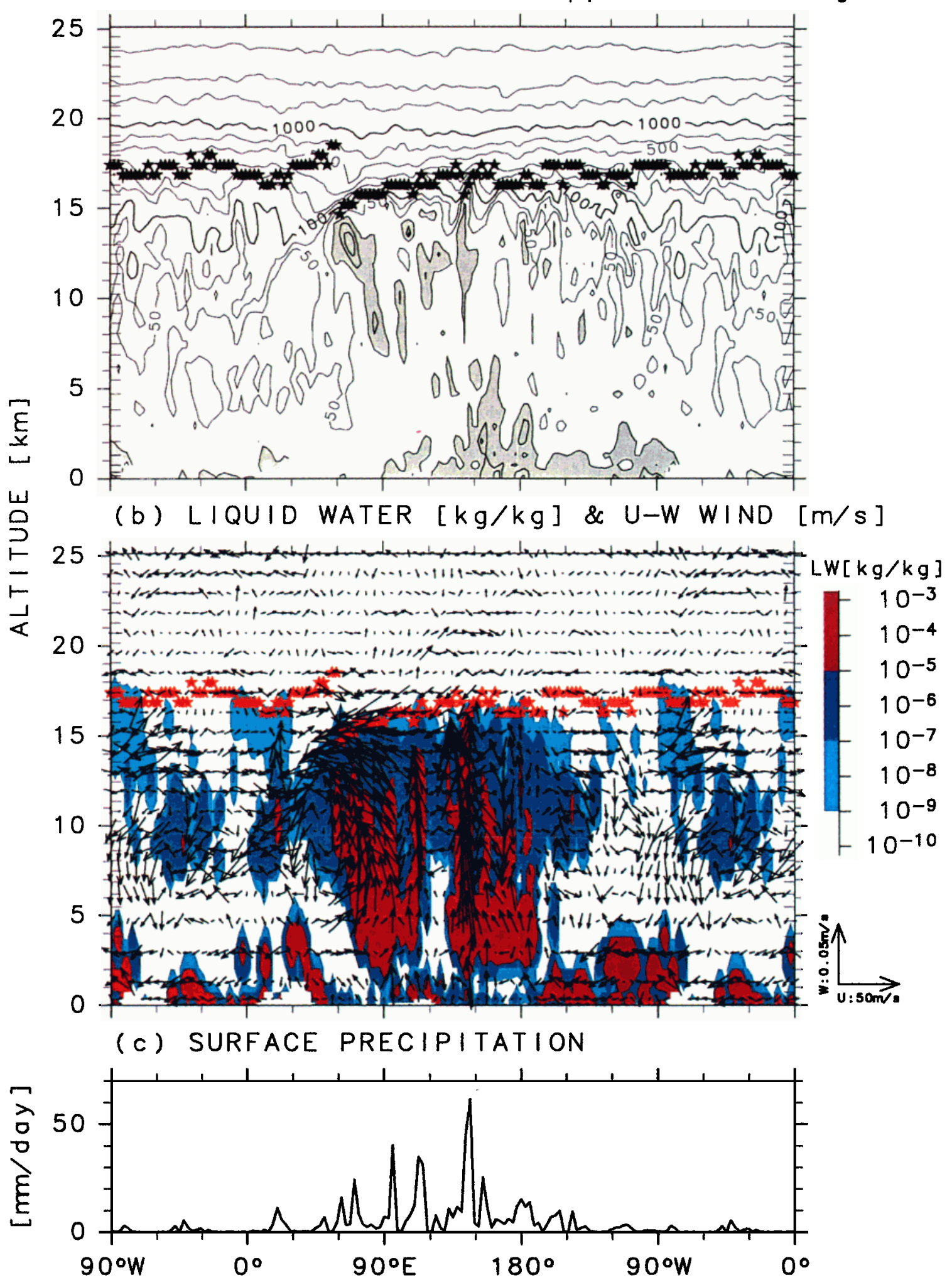

Plate 1. Longitude-altitude distributions of (a) ozone mixing ratio and (b) liquid water and $u-w$ vector, and (c) longitudinal distribution of surface precipitation in $\mathrm{mm} \mathrm{d}^{-1}$ at the equator $\left(1.3953^{\circ} \mathrm{N}\right)$ on August 15 of the fifteenth year. The contour lines for ozone are $[1,1.5,2,3,5$, $7] \times 10^{n} \mathrm{ppbv}$, where $n=1 \sim 3$. The shaded regions for ozone correspond to those of less than $30 \mathrm{ppbv}$. The amount of the vectors in Plate $1 \mathrm{~b}$ is reduced to a fourth. The location of the tropopause defined by the temperature minimum is indicated by stars in Plates 1a and 1b. Note that the region $90^{\circ} \mathrm{W}-0^{\circ}$ is duplicated. 


\section{OZONE MIXING RATIO AT THE TROPOPAUSE $1.3953^{\circ} \mathrm{N}$ \\ Year 15}

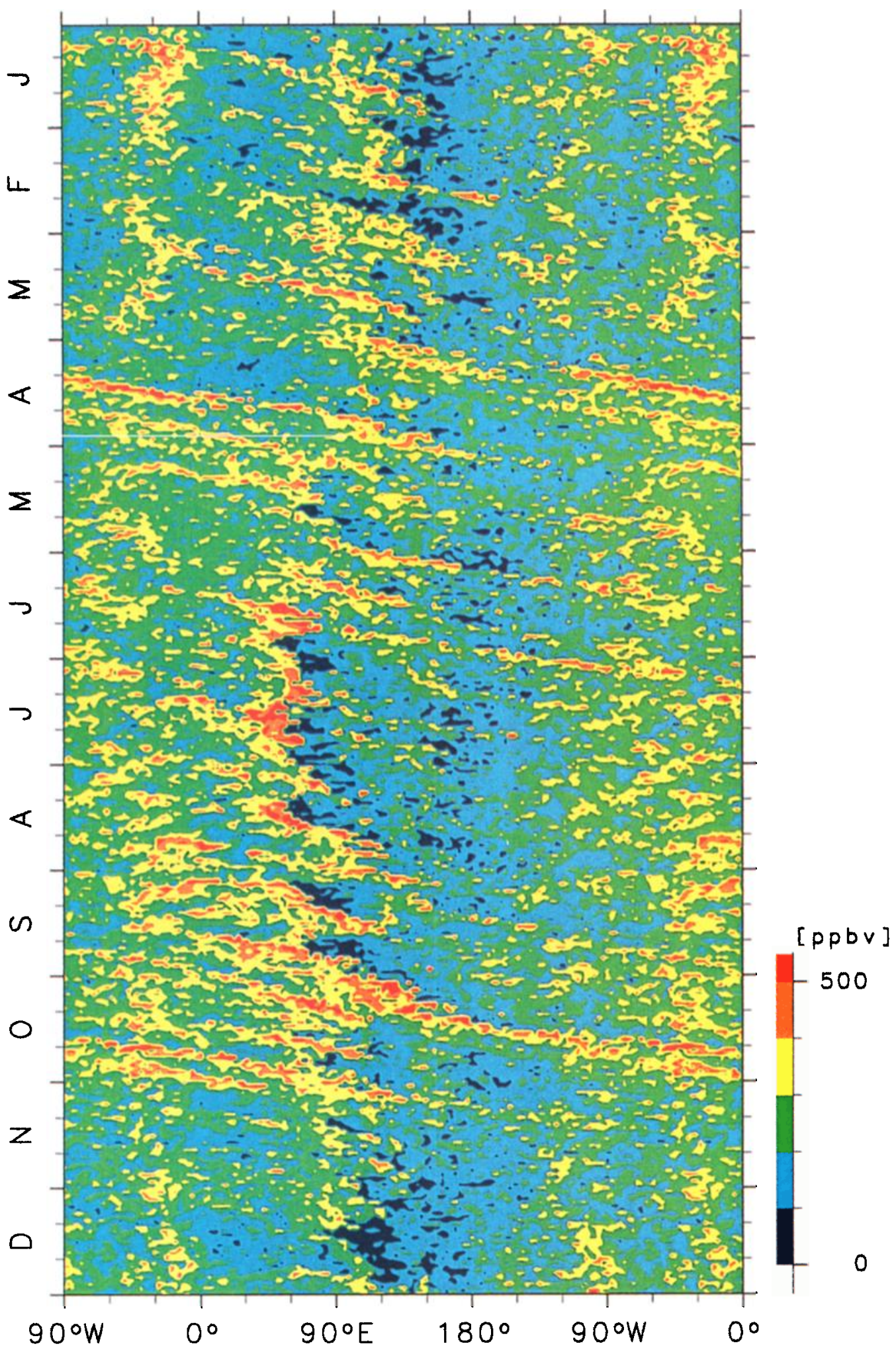

Plate 2. Longitude-time distribution of ozone mixing ratio at the tropopause defined by the temperature minimum at the equator $\left(1.3953^{\circ} \mathrm{N}\right)$ in the fifteenth year. Note that the region $90^{\circ} \mathrm{W}-0^{\circ}$ is duplicated. 


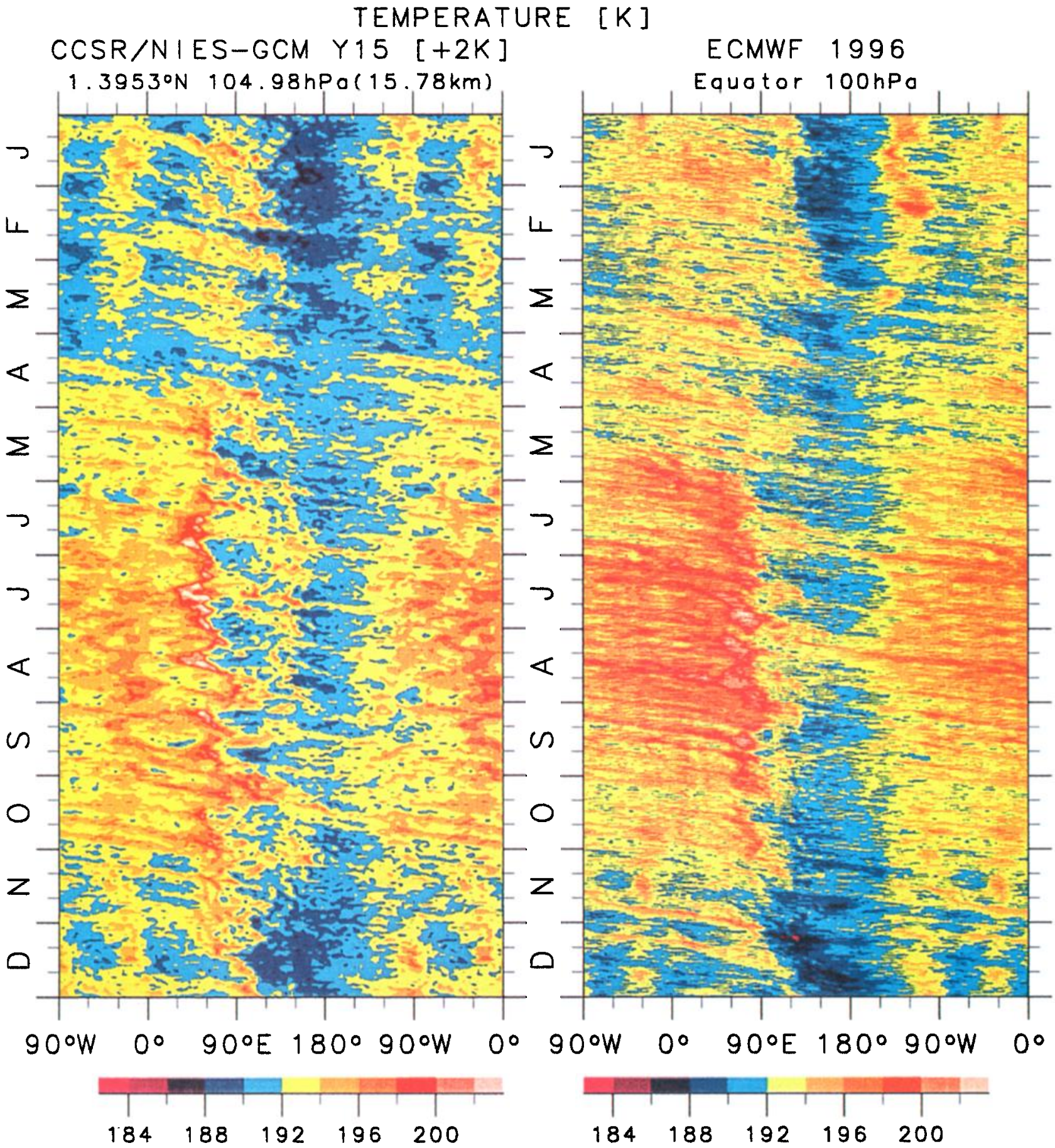

Plate 3. Longitude-time distributions of (left) the Center for Climate System Research/National Institute for Environmental Studies (CCSR/NIES) GCM temperature (2 K added) on $104.98 \mathrm{hPa}$ at the equator $\left(1.3953^{\circ} \mathrm{N}\right.$ ) in the fifteenth year and (right) European Centre for Medium-Range Weather Forecasts (ECMWF) temperature on $100 \mathrm{hPa}$ at the equator in 1996 . The time and spatial resolutions of the ECMWF data are twice daily and $2.5^{\circ} \times 2.5^{\circ}$, respectively. Note that the region $90^{\circ} \mathrm{W}-0^{\circ}$ is duplicated. 


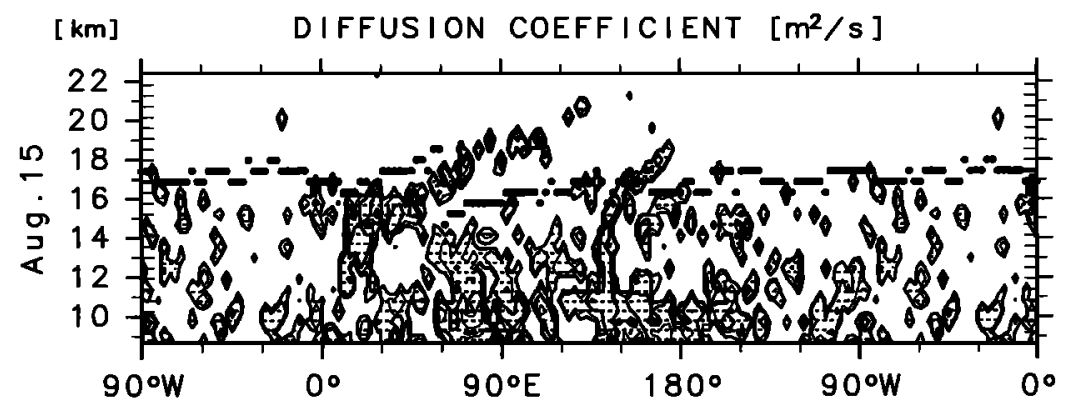

Figure 9. Same as Figure 5 but for vertical diffusion coefficient for minor constituents on August 15. The contour lines are $[1,3] \times 10^{n} \mathrm{~m}^{2} \mathrm{~s}^{-1}$, where $n=2 \sim 5$. The shaded regions correspond to those of more than $100 \mathrm{~m}^{2} \mathrm{~s}^{-1}$.

coupled with organized active convections and zonal circulation in the troposphere. At the downward displacement phase of this Kelvin wave with suppressed convective activity below, a dry, ozone-rich air mass was transported into the upper troposphere. The breaking of this wave also made a contribution to the irreversible transport. At the opposite phase, below which organized cumulonimbus clouds existed, diabatic cooling processes and a thin downward wind layer around the tropopause prevented the lower stratosphere from developing excess water. Therefore the passage of such a Kelvin wave-circulation cell system maintains the dryness around the equatorial tropopause region. This should be one of the important processes controlling the stratospheric water vapor budget. This study also pointed out for global analysis data users that when and where the large-scale gravity waves are dominant, only their cold phases should be chosen to estimate the water vapor concentration around the equatorial tropopause. As for the seasonal and longitudinal characteristics of the activity of such large-scale disturbances, we further analyzed the 4-year integration data and found that eastward moving large-scale gravity waves are dominant at the equatorial tropopause and especially active over the Indian Ocean during the northern summer through autumn. This is probably related to the development of the summer monsoon circulation over south Asia. This model also simulated the zonal wave one structure of tropical tropospheric ozone for the first time and suggested that this structure is a result of the longitudinal difference in convective transport and would exist even in the absence of biomass burning.

One of the keys for this GCM experiment was the vertical resolution of $\sim 550 \mathrm{~m}$, finer than that of other GCMs, to allow simulating a realistic activity of largescale disturbances with a typical vertical wavelength of $\sim 7 \mathrm{~km}$ at $N=2.2 \times 10^{-2} \mathrm{~s}^{-1}$. (Note that the vertical wavelength of the observed case by Fujiwara et al. [1998] was 2.5-5.6 km.) Recently, Mote et al. [2000] presented the observational result of the global tropical $100-\mathrm{hPa}$ water vapor distribution for the first time by using the Microwave Limb Sounder (MLS) on board the
Upper Atmosphere Research Satellite (UARS) and confirmed a dominant contribution of ISO-timescale phenomena. They noted, however, that the MLS $100-\mathrm{hPa}$ water vapor measurement actually represents a $4-\mathrm{km}$ layer. Our study suggests that the vertical resolution should be less than $1 \mathrm{~km}$ to further investigate the tropical tropopause processes even for large-scale phenomena.

As an effective agent for the tropical STE, the cumulonimbus cloud has drawn much attention since the early 1980s. Tropical clouds, however, never exist alone; they tend to be organized to larger-scale cloud disturbances such as cloud clusters and super cloud clusters [e.g., Nakazawa, 1988; Chen et al., 1996] or "convectively coupled Kelvin waves" [e.g., Wheeler and Kiladis, 1999; Wheeler et al., 2000] or even MJO/ISO [e.g., Madden and Julian, 1994]. At and above the top of these organized clouds, large-scale equatorial waves, especially the Kelvin waves, develop to cause minor constituents' variations around the tropopause as shown in the present study. Therefore the equatorial waves and organized clouds are both essential and constitute a large-scale system to cause the tropical STE.

Acknowledgments. A significant part of this study was made when M.F. was at the Department of Earth and Planetary Physics, Graduate School of Science, University of Tokyo. We would like to thank Atusi Numaguti and other staff members responsible for the development of the CCSR/NIES AGCM. We appreciate the kind help of Tatsuya Nagashima and Masayuki Takigawa in performing the experiment. Computations were made on the HITAC S-3800 at the Computer Center of the University of Tokyo. M.F. was supported by research fellowships of the Japan Society for the Promotion of Science for Young Scientists. This study was supported by the Center for Climate System Research of the University of Tokyo and the Grant-in-aid for Scientific Research of Priority Areas (B), grant 11219202. We are grateful to M. Shiotani, N. Nishi, T. Horinouchi, Y. Tomikawa, F. Hasebe, K. Kita, and N. Iwagami for discussion and encouragement. Comments on the manuscript by three anonymous reviewers and P. Mote are greatly appreciated. The GTOOL compiled by A. Numaguti was used for some of the analyses. The figures and plates were produced with the GFD-DENNOU Library. 


\section{References}

Andrews, D. G., J. R. Holton, and C. B. Leovy, Middle Atmosphere Dynamics, 489 pp., Academic, San Diego, Calif., 1987.

Balsley, B. B., W. L. Ecklund, D. A. Carter, A. C. Riddle, and K. S. Gage, Average vertical motions in the tropical atmosphere observed by a radar wind profiler on Pohnpei ( $7^{\circ} \mathrm{N}$ latitude, $157^{\circ} \mathrm{E}$ longitude), J. Atmos. Sci., 45, 396$405,1988$.

Boehm, M. T., and J. Verlinde, Stratospheric influence on upper tropospheric tropical cirrus, Geophys. Res. Lett., 27, 3209-3212, 2000.

Boville, B. A., Middle atmosphere version of CCM2 (MACCM2): Annual cycle and interannual variability, $J$. Geophys. Res., 100, 9017-9039, 1995.

Brewer, A. W., Evidence for a world circulation provided by the measurements of helium and water vapour distribution in the stratosphere, Q. J. R. Meteorol. Soc., 75, 351-363, 1949.

Chen, P., Isentropic cross-tropopause mass exchange in the extratropics, J. Geophys. Res., 100, 16,661-16,673, 1995.

Chen, S. S., R. A. Houze Jr., and B. E. Mapes, Multiscale variability of deep convection in relation to large-scale circulation in TOGA COARE, J. Atmos. Sci., 53, 1380$1409,1996$.

Danielsen, E. F., A dehydration mechanism for the stratosphere, Geophys. Res. Lett., 9, 605-608, 1982.

Dessler, A. E., A reexamination of the "stratospheric fountain" hypothesis, Geophys. Res. Lett., 25, 4165-4168, 1998.

Dobson, G. M. B., Origin and distribution of polyatomic molecules in the atmosphere, Proc. $R$. Soc. London, Ser. A, 236, 187-193, 1956.

Dobson, G. M. B., D. N. Harrison, and J. Lawrence, Measurements of the amount of ozone in the Earth's atmosphere and its relation to other geophysical conditions, III, Proc. R. Soc. London, Ser. A, 122, 456-486, 1929.

Fishman, J., C. E. Watson, J. C. Larsen, and J. A. Logan, Distribution of tropospheric ozone determined from satellite data, J. Geophys. Res., 95, 3599-3617, 1990.

Fujiwara, M., K. Kita, and T. Ogawa, Stratospheretroposphere exchange of ozone associated with the equatorial Kelvin wave as observed with ozonesondes and rawinsondes, J. Geophys. Res., 103, 19,173-19,182, 1998.

Fujiwara, M., K. Kita, S. Kawakami, T. Ogawa, N. Komala, S. Saraspriya, and A. Suripto, Tropospheric ozone enhancements during the Indonesian forest fire events in 1994 and in 1997 as revealed by ground-based observations, Geophys. Res. Lett., 26, 2417-2420, 1999.

Fujiwara, M., K. Kita, T. Ogawa, S. Kawakami, T. Sano, N. Komala, S. Saraspriya, and A. Suripto, Seasonal variation of tropospheric ozone in Indonesia revealed by 5-year ground-based observations, J. Geophys. Res., 105, 18791888, 2000.

Fujiwara, M., F. Hasebe, M. Shiotani, N. Nishi, H. Vömel, and S. J. Oltmans, Water vapor control at the tropopause by equatorial Kelvin waves observed over the Galápagos, Geophys. Res. Lett., 28, 3143-3146, 2001.

Gage, K. S., J. R. McAfee, D. A. Carter, W. L. Ecklund, A. C. Riddle, G. C. Reid, and B. B. Balsley, Long-term mean vertical motion over the tropical Pacific: Wind-profiling Doppler radar measurements, Science, 254, 1771-1773, 1991.

Haynes, P. H., C. J. Marks, M. E. McIntyre, T. G. Shepherd, and K. P. Shine, On the "downward control" of extratropical diabatic circulation by eddy-induced mean zonal forces, J. Atmos. Sci., 48, 651-678, 1991.
Holton, J. R., Troposphere-stratosphere exchange of trace constituents: The water vapor puzzle, in Dynamics of the Middle Atmosphere, edited by J. R. Holton and T. Matsuno, pp. 369-385, Terra Sci., Tokyo, 1984.

Holton, J. R., P. H. Haynes, M. E. McIntyre, A. R. Douglass, R. B. Rood, and L. Pfister, Stratosphere-troposphere exchange, Rev. Geophys., 33(4), 403-439, 1995.

Johnson, R. H., and D. C. Kriete, Thermodynamic and circulation characteristics of winter monsoon tropical mesoscale convection, Mon. Weather Rev., 110, 18981911, 1982.

Kley, D., E. J. Stone, W. R. Henderson, J. W. Drummond, W. J. Harrop, A. L. Schmeltekopf, T. L. Thompson, and R. H. Winkler, In situ measurements of the mixing ratio of water vapor in the stratosphere, J. Atmos. Sci., 36, 2513-2524, 1979.

Koteswaram, P., The easterly jet stream in the tropics, Tellus, 10, 43-57, 1958.

Lindzen, R. S., and M. Fox-Rabinovitz, Consistent vertical and horizontal resolution, Mon. Weather Rev., 117, 25752583, 1989.

Madden, R. A., and P. R. Julian, Description of global-scale circulation cells in the tropics with a 40-50 day period, $J$. Atmos. Sci., 29, 1109-1123, 1972.

Madden, R. A., and P. R. Julian, Observations of the 40-50day tropical oscillation - A review, Mon. Weather Rev., 122, 814-837, 1994.

Matsuno, T., Quasi-geostrophic motions in the equatorial area, J. Meteorol. Soc. Jpn., 44, 25-43, 1966.

McFarlane, N. A., The effect of orographically excited gravity wave drag on the general circulation of the lower stratosphere and troposphere, J. Atmos. Sci., 44, 1775$1800,1987$.

McPeters, R. D., D. F. Heath, and P. K. Bhartia, Average ozone profiles for 1979 from the Nimbus 7 SBUV instrument, J. Geophys. Res., 89, 5199-5214, 1984.

Mellor, G. L., and T. Yamada, A hierarchy of turbulence closure models for planetary boundary layers, J. Atmos. Sci., 31, 1791-1806, 1974.

Mote, P. W., K. H. Rosenlof, M. E. McIntyre, E. S. Carr, J. C. Gille, J. R. Holton, J. S. Kinnersley, H. C. Pumphrey, J. M. Russell III, and J. W. Waters, An atmospheric tape recorder: The imprint of tropical tropopause temperatures on stratospheric water vapor, J. Geophys. Res., 101, 3989-4006, 1996.

Mote, P. W., H. L. Clark, T. J. Dunkerton, R. S. Harwood, and $H$. C. Pumphrey, Intraseasonal variations of water vapor in the tropical upper troposphere and tropopause region, J. Geophys. Res., 105, 17,457-17,470, 2000.

Nagashima, T., M. Takahashi, and F. Hasebe, The first simulation of an ozone QBO in a general circulation model, Geophys. Res. Lett., 25, 3131-3134, 1998.

Nakajima, T., M. Tsukamoto, Y. Tsusima, and A. Numaguti, Modeling of the radiative process in an AGCM, in Reports of a New Program for Creative Basic Research Studies, Studies of Global Environment Change With Special Reference to Asia and Pacific Regions, Rep. I-3, pp. 104-123, Cent. for Clim. Syst. Res., Tokyo, 1995.

Nakazawa, T., Tropical super clusters within intraseasonal variations over the western Pacific, J. Meteorol. Soc. Jpn., 66, 823-839, 1988.

Newell, R. E., and S. Gould-Stewart, A stratospheric fountain?, J. Atmos. Sci., 38, 2789-2796, 1981.

Nishi, N., and A. Sumi, Eastward-moving disturbance near the tropopause along the equator during the TOGA COARE IOP, J. Meteorol. Soc. Jpn., 73, 321-337, 1995.

Numaguti, A., Dynamics and energy balance of the Hadley circulation and the tropical precipitation zone: Signifi- 
cance of the distribution of evaporation, J. Atmos. Sci., 50, 1874-1887, 1993.

Numaguti, A., Origin and recycling processes of precipitating water over the Eurasian continent: Experiments using an atmospheric general circulation model, J. Geophys. Res., 104, 1957-1972, 1999.

Numaguti, A., M. Takahashi, T. Nakajima, and A. Sumi, Development of an atmospheric general circulation model, in Reports of a New Program for Creative Basic Research Studies, Studies of Global Environment Change With Special Reference to Asia and Pacific Regions, Rep. I-3, pp. 1-27, Cent. for Clim. Syst. Res., Tokyo, 1995.

Parker, D. E., Equatorial Kelvin waves at 100 millibars, $Q$. J. R. Meteorol. Soc., 99, 116-129, 1973.

Potter, B. E., and J. R. Holton, The role of monsoon convection in the dehydration of the lower tropical stratosphere, J. Atmos. Sci., 52, 1034-1050, 1995.

Sherwood, S. C., A "stratospheric drain" over the maritime continent, Geophys. Res. Lett., 27, 677-680, 2000.

Shiotani, M., Annual, quasi-biennial, and El Niño-Southern Oscillation (ENSO) time-scale variations in equatorial total ozone, J. Geophys. Res., 97, 7625-7633, 1992.

Shiotani, M., and F. Hasebe, Stratospheric ozone variations in the equatorial region as seen in Stratospheric Aerosol and Gas Experiment data, J. Geophys. Res., 99, 14,57514,584, 1994.

Takahashi, M., Simulation of the stratospheric quasibiennial oscillation using a general circulation model, Geophys. Res. Lett., 23, 661-664, 1996.

Takahashi, M., Simulation of the quasi-biennial oscillation in a general circulation model, Geophys. Res. Lett., 26 , 1307-1310, 1999.

Takahashi, M., N. Zhao, and T. Kumakura, Equatorial waves in a general circulation model simulating a quasibiennial-oscillation, J. Meteorol. Soc. Jpn., 75, 529-540, 1997.

Tsuda, T., Y. Murayama, H. Wiryosumarto, S. W. B. Harijono, and S. Kato, Radiosonde observations of equatorial atmosphere dynamics over Indonesia, 1, Equatorial waves and diurnal tides, J. Geophys. Res., 99, 10,491-10,505, 1994.
Vömel, H., and S. J. Oltmans, Comment on "A reexamination of the 'stratospheric fountain' hypothesis" by A. E. Dessler, Geophys. Res. Lett., 26, 2737-2738, 1999.

Vömel, H., S. J. Oltmans, D. Kley, and P. J. Crutzen, New evidence for the stratospheric dehydration mechanism in the equatorial Pacific, Geophys. Res. Lett., 22, 3235-3238, 1995.

Wallace, J. M., and V. E. Kousky, Observational evidence of Kelvin waves in the tropical stratosphere, J. Atmos. Sci., 25, 900-907, 1968.

Wang, B., and X. Xie, A model for the boreal summer intraseasonal oscillation, J. Atmos. Sci., 54, 72-86, 1997.

Wang, P.-H., P. Minnis, M. P. McCormick, G. S. Kent, and K. M. Skeens, A 6-year climatology of cloud occurrence frequency from Stratospheric Aerosol and Gas Experiment II observations (1985-1990), J. Geophys. Res., 101, 29,407-29,429, 1996.

Wheeler, M., and G. N. Kiladis, Convectively coupled equatorial waves: Analysis of clouds and temperature in the wavenumber-frequency domain, J. Atmos. Sci., 56, 374399, 1999.

Wheeler, M., G. N. Kiladis, and P. J. Webster, Largescale dynamical fields associated with convectively coupled equatorial waves, J. Atmos. Sci., 57, 613-640, 2000.

Winker, D. M., and C. R. Trepte, Laminar cirrus observed near the tropical tropopause by LITE, Geophys. Res. Lett., 25, 3351-3354, 1998.

Ziemke, J. R., S. Chandra, A. M. Thompson, and D. P. McNamara, Zonal asymmetries in Southern Hemisphere column ozone: Implications of biomass burning, $J$. Geophys. Res., 101, 14,421-14,427, 1996.

M. Fujiwara, Radio Science Center for Space and Atmosphere (RASC), Kyoto University, Uji, Kyoto 611-0011, Japan. (fuji@kurasc.kyoto-u.ac.jp)

M. Takahashi, Center for Climate System Research, University of Tokyo, Tokyo 153-8904, Japan. (masaaki@ccsr.utokyo.ac.jp)

(Received November 14, 2000; revised March 28, 2001; accepted April 19, 2001.) 